OAK RIDGE

NATIONAL LABORATORY

MANAGED BY UT-BATTELLE

FOR THE LEPARTMENT OF ENERGY

\title{
Independent Verification Survey of the Clean Coral Storage Pile at the Johnston Atoll Plutonium Contaminated Soil Remediation Project
}

M. J. Wilson-Nichols

$$
\text { P. V. Egidi }
$$

E. K. Roemer

R. M. Schlosser 


\title{
INDEPENDENT VERIFICATION SURVEY OF THE CLEAN CORAL STORAGE PILE AT THE JOHNSTON ATOLL PLUTONIUM CONTAMINATED SOIL REMEDIATION PROJECT
}

\author{
M. J. Wilson-Nichols \\ P. V. Egidi \\ E. K. Roemer \\ R. M. Schlosser
}
Environmental Technology Section
Life Sciences Division
Grand Junction, Colorado

Date Published: September 2000

\author{
Prepared for the \\ Field Command Defense Threat Reduction Agency \\ 1680 Texas Street SE \\ Kirtland, NM 87117-5667 \\ Prepared by the \\ OAK RIDGE NATIONAL LABORATORY \\ Oak Ridge, Tennessee 37831 \\ managed by \\ UT-BATTELLE, LLC \\ for the \\ U.S. DEPARTMENT OF ENERGY \\ under contract DE-AC05-00OR22725
}




\section{CONTENTS}

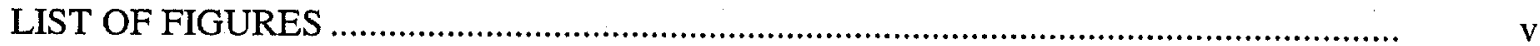

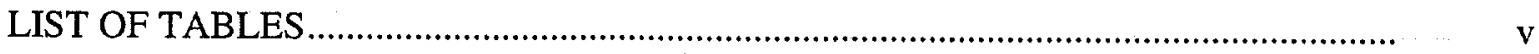

ACRONYMS AND ABBREVIATIONS …............................................................ vii

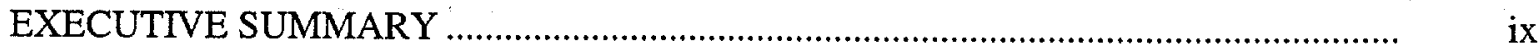

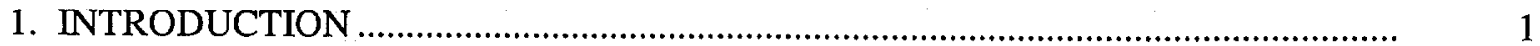

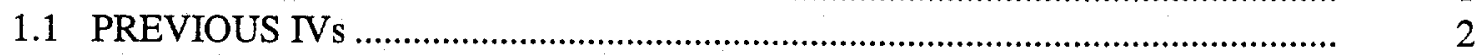

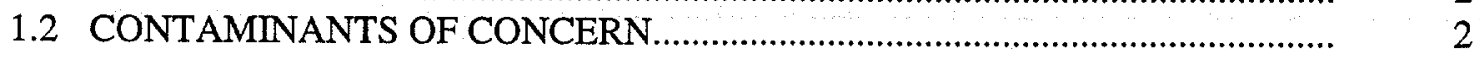

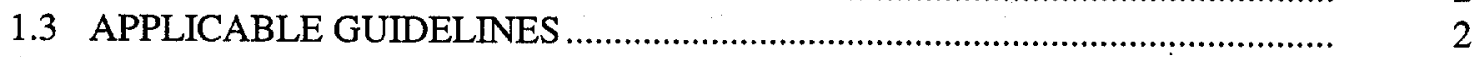

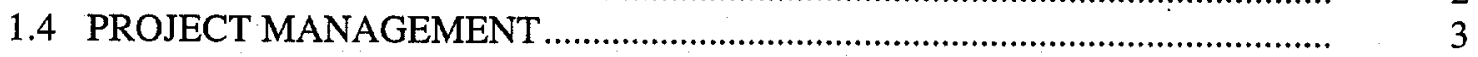

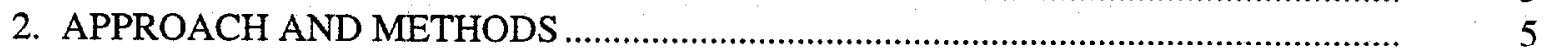

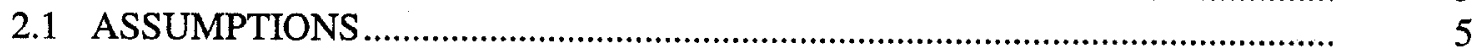

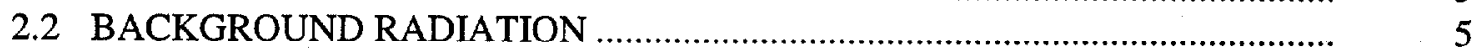

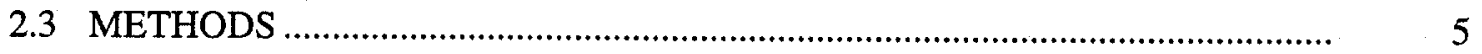

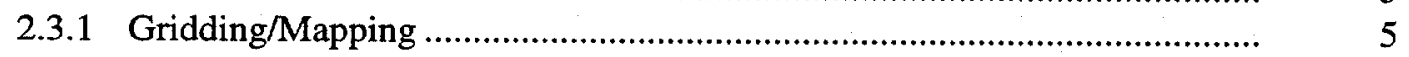

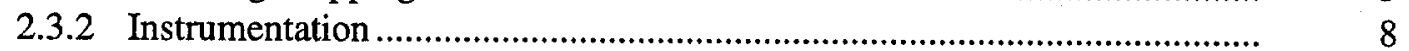

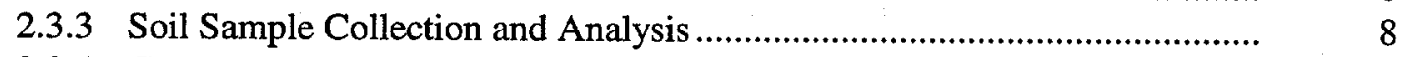

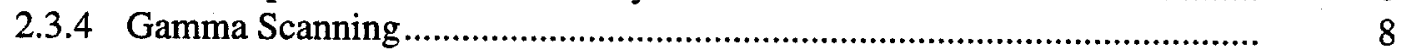

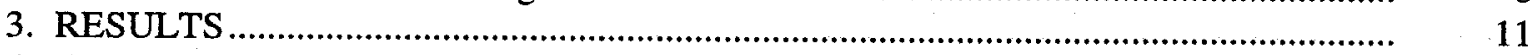

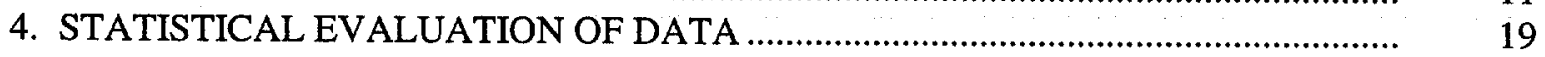

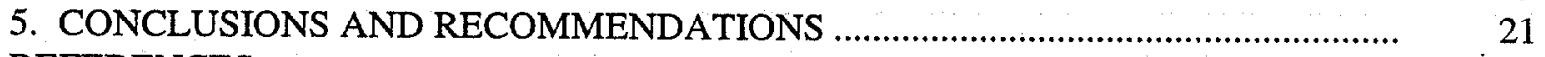

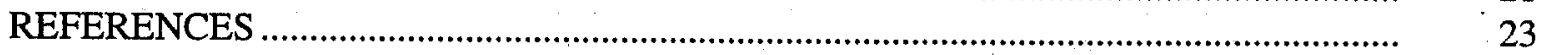

Appendix A. PHOTOGRAPH LOG ......................................................................... A-1

Appendix B. RESULTS FROM ON-SITE RADIOANALYTICAL LABORATORY ........ B-1

Appendix C. QC RESULTS FROM ORNL ANAL YTICAL LABORATORY …............... . C-1 


\section{LIST OF FIGURES}

Figure

Page

JA showing RCA

Overlay of 10 - by $10-\mathrm{m}$ grid on clean storage pile.

Soil sample locations

Results of surface gamma scan on selected grid blocks................................

On-site vs QC results.................................................................................. 17

Distribution of results .............................................................................. 19

A.2 Looking east at concrete rubble and the analytical laboratory at the

Looking north-northwest at lagoon from the plutonium

decommissioning site

plutonium decommissioning site

Collecting coral samples at 1 - to 4 -ft depths from the clean pile...

Waste storage at the plutonium decontamination project

Looking northeast at the clean storage pile.

\section{LIST OF TABLES}

Sample locations and depths

Total TRU in coral samples from clean storage pile..

Results of confirmatory analysis for total TRU

Results of radiochemistry....

Radiochemistry vs gamma spectral results .

Fixed point measurements at grid point locations .

Summary statistics 


\section{ACRONYMS AND ABBREVIATIONS}

$\begin{array}{ll}\text { Am } & \text { americium } \\ \text { ANS } & \text { American Nuclear Systems } \\ \text { ASO } & \text { Analytical Services Organization } \\ \text { Bq } & \text { bequerel } \\ \text { Ci } & \text { curie } \\ \text { cm } & \text { centimeter } \\ \text { DCGL } & \text { derived concentration guideline level } \\ \text { DTRA } & \text { Defense Threat Reduction Agency } \\ \text { ETS } & \text { Environmental Technology Section } \\ \text { FCDTRA } & \text { Field Command Defense Threat Reduction Agency } \\ \text { FIDLER } & \text { field instrument for the detection of low-energy radiation } \\ \text { ft } & \text { feet } \\ \text { g } & \text { gram } \\ \text { h } & \text { hour } \\ \text { IV } & \text { Independent Verification } \\ \text { JA } & \text { Johnston Atoll } \\ \text { JAPCSRP } & \text { Johnston Atoll Plutonium Contaminated Soil Remediation Project } \\ \mathrm{k} & \text { kilo } \\ \text { keV } & \text { kiloelectron volt } \\ \mathrm{m} & \text { meter } \\ \text { MARSSIM } & \text { Multi-Agency Radiological Site Survey Investigation Manual } \\ \text { MDC } & \text { minimum detectable concentration } \\ \text { MDCR } & \text { minimum detectable concentration rate } \\ \text { min } & \text { minute } \\ \text { n } & \text { nano } \\ \text { ORNL } & \text { Oak Ridge National Laboratory } \\ \text { p } & \text { pico } \\ \text { Pu } & \text { plutonium } \\ \text { QC } & \text { quality control } \\ \text { RCA } & \text { radiological control area } \\ \text { RPD } & \text { relative percent difference } \\ \text { SAP } & \text { sampling and analysis plan } \\ \text { TRU } & \text { transuranic } \\ \text { VSP } & \text { Visual Sample Plan } \\ & \end{array}$


$\pi$ 


\section{EXECUTIVE SUMMARY}

The Oak Ridge National Laboratory (ORNL) Environmental Technology Section conducted an independent verification (IV) survey of the clean storage pile at the Johnston Atoll Plutonium Contaminated Soil Remediation Project (JAPCSRP) from January 18-25, 1999.

The goal of the JAPCSRP is to restore a 24 -acre area that was contaminated with plutonium oxide particles during nuclear testing in the 1960s. The selected remedy was a soil sorting operation that combined radiological measurements and mining processes to identify and sequester plutonium-contaminated soil. The soil sorter operated from about 1990 to 1998 . The remaining clean soil is stored on-site for planned beneficial use on Johnston Island. The clean storage pile currently consists of approximately $120,000 \mathrm{~m}^{3}$ of coral.

ORNL conducted the survey according to a Sampling and Analysis Plan, which proposed to provide an IV of the clean pile by collecting a minimum number (99) of samples. The goal was to ascertain with $95 \%$ confidence whether $97 \%$ of the processed soil is less than or equal to the accepted guideline (500-Bq/kg or $13.5-\mathrm{pCi} / \mathrm{g}$ ) total transuranic (TRU) activity.

In previous IV tasks, ORNL has (1) evaluated and tested the soil sorter system software and hardware and (2) evaluated the quality control (QC) program used at the soil sorter plant. The IV has found that the soil sorter decontamination was effective and significantly reduced plutonium contamination in the soil processed at the JA site. The Field Command Defense Threat Reduction Agency currently plans to re-use soil from the clean pile as a cover to remaining contamination in portions of the radiological control area. Therefore, ORNL was requested to provide an IV.

The survey team collected samples from 103 random locations within the top $4 \mathrm{ft}$ of the clean storage pile. The samples were analyzed in the on-site radioanalytical counting laboratory with an American Nuclear Systems (ANS) field instrument used for the detection of low-energy radiation. Nine results exceeded the JA soil screening guideline for distributed contamination of $13.5 \mathrm{pCi} / \mathrm{g}$ for total TRUs, ranging from 13.7 to $125.9 \mathrm{pCi} / \mathrm{g}$. Because of these results, the goal of showing with $95 \%$ confidence that $97 \%$ of the processed soil is less than or equal to $13.5 \mathrm{pCi} / \mathrm{g}$ TRU activity cannot be met. The value of $13.5 \mathrm{pCi} / \mathrm{g}$ represents the 88 th percentile rather than the 95 th percentile in a nonparametric one-sided upper $90 \%$ confidence limit. Therefore, at the $95 \%$ confidence level, $88 \%$ of the clean pile is projected to be below the $13.5-\mathrm{pCi} / \mathrm{g}$ goal.

The Multi-Agency Radiation Survey and Site Investigation Manual recommends use of a nonparametric statistical "Sign Test" to demonstrate compliance with release criteria for TRU. Although this survey was not designed to use the sign test, the data herein would demonstrate that the median (50\%) of the clean storage pile is below the $13.5-\mathrm{pCi} / \mathrm{g}$ derived concentration guideline level. In other words, with the caveat that additional investigation of elevated concentrations was not performed, the data pass the sign test at the $13.5-\mathrm{pCi} / \mathrm{g}$ level.

Additionally, the lateral extent of the pile was gridded, and $10 \%$ of the grid blocks was scanned with field instruments for the detection of low-energy radiation coupled to ratemeter/ scalers to screen for the presence of hot particles. No hot particles were detected in the top $1 \mathrm{~cm}$ of the grid blocks surveyed. 


\section{INTRODUCTION}

This report describes an independent verification (IV) survey of the clean coral storage pile (clean pile) at the Johnston Atoll Plutonium Contaminated Soil Remediation Project (JAPCSRP) from January 18-25, 1999. A photograph $\log$ of the site and survey effort is provided in Appendix A. Johnston Atoll (JA), an unincorporated territory of the United States, consists of four primarily manmade islands approximately 800 miles west-southwest of Hawaii. Contamination from plutonium $(\mathrm{Pu})$ and americium $(\mathrm{Am})$ is a result of THOR missile aborts during a 1962 testing series. Cleanup that employed mining techniques to remediate contaminated soil was discontinued in 1998 (DNA 1992). The techniques involved a soil cleanup plant (soil sorter) that sorted out contamination to allow recycling of uncontaminated soil.

In 1992, the Field Command Defense Threat Reduction Agency (FCDTRA) contracted the Oak Ridge National Laboratory (ORNL) Environmental Technology Section (ETS) to provide IV support at the JAPCSRP. The objective of an IV is to assure that the cleanup criteria, standards, and/or guidelines specific to JA contamination are appropriately applied and met. The purpose of IV is to validate the accuracy and completeness of field measurements and the credibility of procedures followed, resulting in an independent assessment of site conditions. The goal of the independent assessment is to document that radiological contamination on the island no longer poses a threat to human health or the environment.

Figure 1 shows the location of the 24-acre radiological control area (RCA) on JA, where the clean pile currently resides, consisting of approximately $120,000 \mathrm{~m}^{3}$ of clean coral. The pile encompasses $175,000 \mathrm{ft}^{2}\left(16,257 \mathrm{~m}^{2}\right)$ and is approximately 8 - $\mathrm{ft}(2.4-\mathrm{m})$ deep. Further historical and background information about the project can be found in the ORNL IV report on the project (ORNL 1998a).

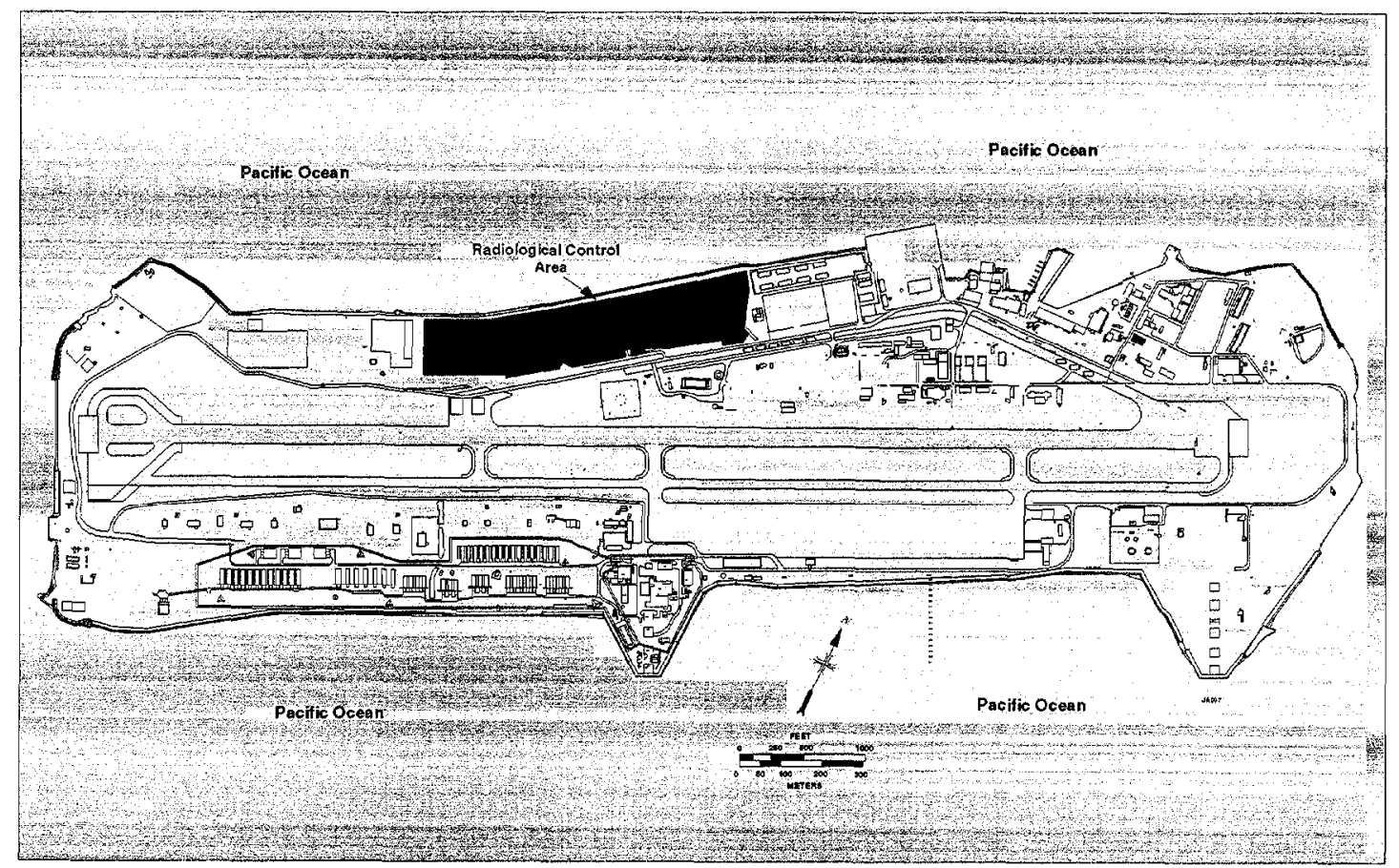

Fig. 1. JA showing RCA. 
ORNL proposed to provide an IV of the clean pile by collecting a minimum number (99) of samples. These samples were collected to show with $95 \%$ confidence that $97 \%$ of the processed soil is less than or equal to the guideline established by FCDTRA of $500-\mathrm{Bq} / \mathrm{kg}$ or $13.5-\mathrm{pCi} / \mathrm{g}$ total transuranic (TRU) activity. This was agreed upon by FCDTRA after review of a proposal in June 1998 (ORNL 1998b).

A Sampling and Analysis Plan (SAP) was developed and provided details of the survey design (ORNL 1999). The locations of the samples were selected randomly by using specialized computer software and were located using a 10 - by $10-\mathrm{m}$ grid placed over the areal extent of the pile. Finally, $10 \%$ of the grid blocks was selected randomly for gamma scanning to determine if hot particles were present in the top $1 \mathrm{~cm}$ of the pile.

\subsection{PREVIOUS IVs}

In previous IV tasks (ORNL 1998a), ORNL has (1) evaluated and tested the soil sorter system software and hardware and (2) evaluated the quality control (QC) program used at the soil sorter plant. The IV has found that the soil sorter decontamination was effective and significantly reduced plutonium contamination in the soil processed at the JA site. The FCDTRA plans to use soil from the clean pile to cover remaining contamination in portions of the RCA. Therefore, FCDTRA requested ORNL to provide a final IV of the radiological condition of the material comprising the clean pile.

\subsection{CONTAMINANTS OF CONCERN}

Contamination from the missile launches is insoluble plutonium oxide $\left(\mathrm{PuO}_{2}\right)$ present as dispersed activity (volume) and hot particles (point sources) (DNA 1991). Particles approximately $10 \mu \mathrm{m}$ in diameter, with approximately $10 \mathrm{~Bq}$ of TRU activity, are widely dispersed; the plutonium apparently had been dissolved as carbonate complexes, which were subsequently adsorbed to the coral surface (Wolf et al. 1995). Discrete, hot particles $(<45 \mu \mathrm{m}$ in diameter with an activity $>1 \mathrm{kBq}$ ) are not so widely dispersed and are found relatively near the source of contamination. At this time, erosion appears to be the primary process affecting migration and distribution of the plutonium. The contamination from the missile launches includes TRUs [elements of the actinide series including plutonium isotopes and $\left.\mathrm{Am}-241\left({ }^{241} \mathrm{Am}\right)\right]$. The ${ }^{241} \mathrm{Am}$ is the daughter product of ${ }^{241} \mathrm{Pu}$, which has a 14.35 -year half-life. The primary types of radiation associated with TRUs are alpha radiation, characteristic X-rays from ${ }^{239} \mathrm{Pu}$, and $60-\mathrm{keV}$ gamma from ${ }^{241} \mathrm{Am}$.

\subsection{APPLICABLE GUIDELINES}

The guideline for the sorter plant assigned by FCDTRA for distributed and particulate contamination was $500 \mathrm{~Bq} / \mathrm{kg}(13.5 \mathrm{pCi} / \mathrm{g})$ total TRU averaged over $0.1 \mathrm{~m}^{3}$ and $5000 \mathrm{~Bq}(135 \mathrm{nCi})$ total TRU per hot particle, respectively. ORNL has evaluated and agreed with the soil-screening limit during past IV tasks (ORNL 1998a). Because it is economically unfeasible to verify that no hot particles over $5000 \mathrm{~Bq}$ exist in 80,000 metric tons of material, the survey used the distributed guideline as its goal. However, gamma scans conducted over approximately $10 \%$ of the surface area of the clean pile provided a general assessment of whether there is an abundance of remaining hot particles. The Defense Threat Reduction Agency (DTRA) requested that the survey use the Multi-Agency Radiological Site Survey Investigation Manual (MARSSIM) (U.S. EPA 1997) as a general guide, and therefore, the screening limit was adopted as the derived concentration guideline level (DCGL) for this task. Data were evaluated using the nonparametric one-sided upper confidence limits on percentiles statistical test for the distributed DCGL. The MARSSIM also 
recommends use of a nonparametric statistical "Sign Test" to demonstrate compliance with release criteria for TRU. Therefore, the sign test was also conducted for additional information. The analyses were performed for ${ }^{241} \mathrm{Am}$; the resulting concentration values are multiplied by a factor of 6.17 total TRU alpha per picocuric of ${ }^{241} \mathrm{Am}$.

\section{PROJECT MANAGEMENT}

Key project personnel and project responsibilities are as follows:

FCDTRA Project Manager

FCDTRA Site Contact

ORNL Project Manager

ORNL Field Operations Leader/

Instrumentation Specialist

ORNL Field Characterization Leader/

Health Physics Technician

ORNL H\&S Technician/

Graphics Technician

Consulting Statistician
Captain David Rynders

SFC John Olson

Mary Wilson-Nichols

Philip V. Egidi

Robert L. Schlosser

Edward Roemer

James R. Davidson
(505) 846-8445

(808) 441-2051

(970) 248-6232

(970) 248-6189

(970) 248-6261

(970) 248-6217

(509) $375-2808$ 


\section{APPROACH AND METHODS}

\subsection{ASSUMPTIONS}

To use the statistical approach described in the sampling and analysis plan (SAP), it was assumed that the material in the outer $4 \mathrm{ft}$ of the clean pile is the same as its core. This is reasonable because the material has been crushed and sorted, and with $95 \%$ confidence Thermo NUTech (the remedial action contractor) thinks that particles exceeding the guideline have been diverted by the system. Therefore, sampling was performed on the outer accessible $4 \mathrm{ft}$ of the clean pile material. Obtaining deeper samples would be costly and logistically difficult and would require heavy equipment that would alter the condition of the pile. The clean pile is classified as a Class II area under MARSSIM nomenclature (U.S. EPA 1997); that is, areas have a potential for radioactive contamination or known contamination, but are not expected to exceed the DCGL. Because the soil was contaminated and has a potential for residual contamination, but is not expected to exceed the DCGL (hot particles are not part of the scope of the statistical test), a Class II designation is appropriate. The area was treated as one survey unit. The hypothesis planned for testing follows:

$\mathrm{H}_{\mathrm{O}}$ : The one-sided upper $95 \%$ confidence limit for the 97 th percentile is greater than or equal to $13.5 \mathrm{pCi} / \mathrm{g}$ (i.e., the survey unit is contaminated).

$\mathrm{H}_{\mathrm{A}}$ : The one-sided $95 \%$ confidence limit for the 97 th percentile is less than $13.5 \mathrm{pCi} / \mathrm{g}$ (i.e., the survey unit is not contaminated).

\subsection{BACKGROUND RADIATION}

The MARSSIM methodology uses two approaches to radiological surveys: (1) surveys for radionuclides present in background and (2) surveys for radionuclides not present in background. Weapons-grade TRUs are not naturally present in background in measurable quantities, but at JA are ubiquitous because of the high-altitude tests conducted there historically. This is the reason that two guidelines were established for cleanup, a distributed DCGL and a hot particle DCGL. Estimating background concentrations according to MARSSIM requires an area unaffected by site operations that is of similar geology. This is not possible at JA because all the islands were exposed to fallout from the atmospheric tests originating from the site. Therefore, results of sample analyses will be directly compared to the distributed soil limit. Ambient gamma will be subtracted by the spectroscopy system as a routine function of the system. Qualitative field measurements collected also account for ambient gamma fluence detected by the instruments.

\subsection{METHODS}

\subsubsection{Gridding/Mapping}

A grid was established on the clean pile using local monuments and benchmarks. The grid was laid out in 10- by $10-\mathrm{m}$ increments (Fig. 2). The grid was tied into the local survey coordinare system by overlaying the grid on existing electronic maps. A computer program, Visual Sample Plan (VSP) (ORNL 1998b), was used to place 103 sample locations in a simple random fashion using quasi-random placement to avoid clustering. The map coordinates ( $\mathrm{X}, \mathrm{Y}$ coordinates) were provided by VSP, and sampling points marked with pin flags. The depths of the samples ( $\mathrm{Z}$ coordinate) were selected randomly from 0 to $4 \mathrm{ft}$ using a random number generator. Figure 3 



Fig. 2. Overlay of $10-$ by $10-\mathrm{m}$ grid on clean storage pile. 

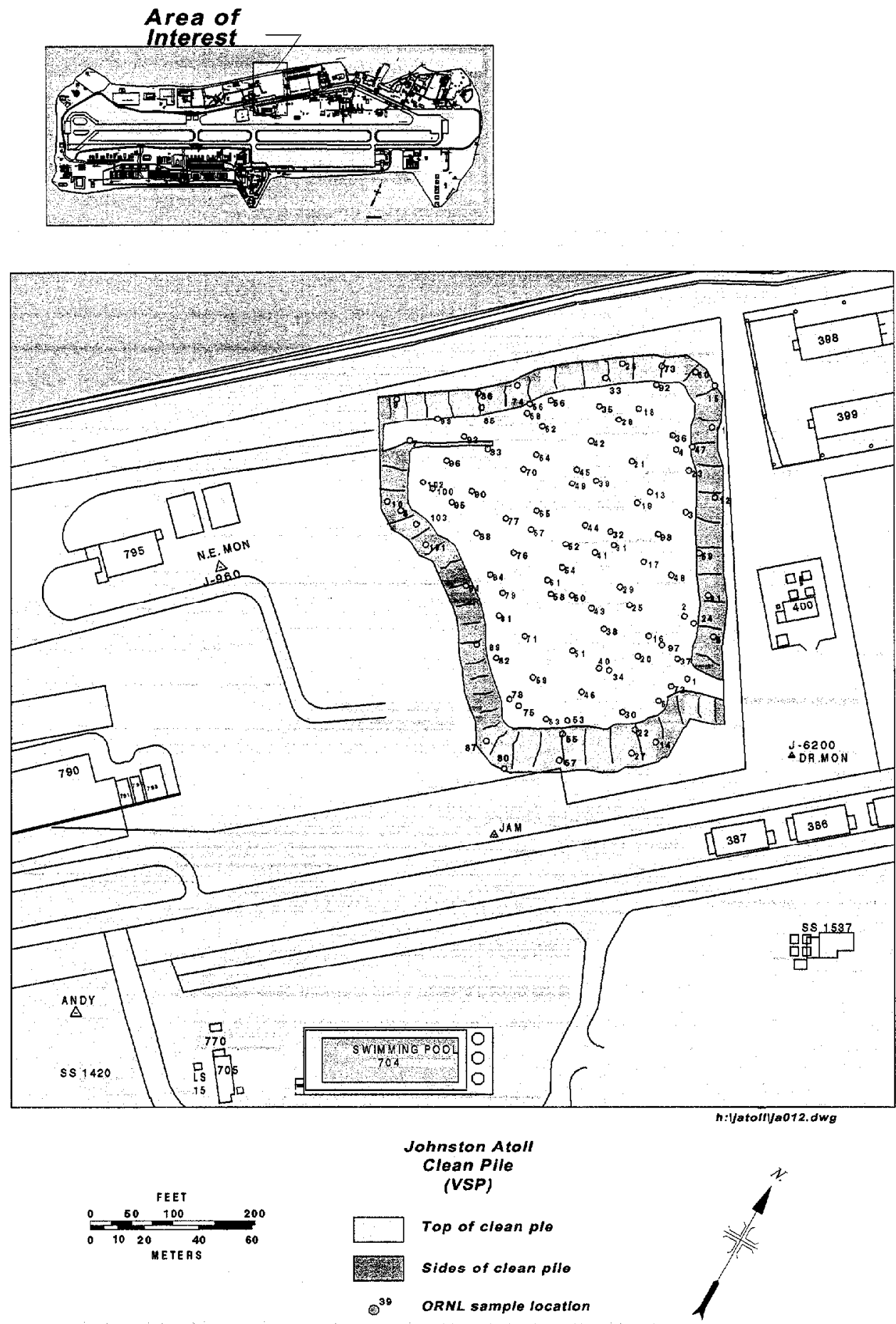

Fig. 3. Soil sample locations. 
and Table 1 show a generalized conception of the clean pile, random sample locations, and sample depths and coordinates.

\subsubsection{Instrumentation}

Three types of radiological instrumentation were used during the survey. Alpha scintillation detectors were used for frisking personnel going in and out of the RCA and for checking sampling equipment after decontamination. Field instruments for the detection of low-energy radiation (FIDLERs) coupled to ratemeter/scalers were used for scanning and screening of the pile, and an on-island gamma spectroscopy system was used for analyzing the samples after collection. The FIDLERs and alpha scintillometers were calibrated at the ORNL facility in Grand Junction using approved U.S. Department of Energy (DOE) methods, which also follow ANSI N323. Table 2 lists instrument parameters.

Operational checks were conducted at the beginning and midpoint of each sample day for the FIDLERs, which are susceptible to humidity and temperature fluctuations. The alpha scintillometers and gamma spectrometers were checked daily. Care, maintenance, and operation were recorded in the instrument logbook. Field personnel updated the instrument logbook at each operational field check.

\subsubsection{Soil Sample Collection and Analysis}

Sampling was conducted using a Geoprobe ${ }^{\circledR}$ brand sampler with an approximate size of 2.5 by $30 \mathrm{~cm}$. The sampler was driven to the desired depth using handheld power tools (hammer drill). After the sample was recovered, it was placed in a plastic bag. A discrete measurement was taken using a FIDLER. The material was blended, sieved through a 10-mesh sieve, and dried at $100^{\circ} \mathrm{C}$ for a minimum of $12 \mathrm{~h}$. An aliquot of material (approximately $100 \mathrm{~g}$ ) was placed in a petri dish, sealed, and labeled (see photograph log, Appendix A). Sample excess was archived on JA. Decontamination of sampling equipment consisted of wiping with a wire brush and screening with an alpha scintillometer.

Samples were analyzed after collection using the on-site gamma spectroscopy. Samples were counted for $15 \mathrm{~min}$, yielding sample results for TRU and minimum detectable concentrations (MDCs) in picocuries per gram. Results of the analysis were kept on the spectrometer system as well as copied over to laptop computer for data manipulation.

All soil samples were packaged and shipped to ORNL in Oak Ridge, Tennessee, for confirmatory analysis and archival. Confirmatory analysis was performed on $\sim 30 \%$ of samples by gamma spectroscopy (using hyperpure germanium detection) for ${ }^{241} \mathrm{Am}$. Also, analysis of four samples $(\sim 10 \%)$ for ${ }^{241} \mathrm{Am},{ }^{239 / 240} \mathrm{Pu}$, ${ }^{238} \mathrm{Pu}$, and ${ }^{243 / 244} \mathrm{Cm}$ was performed by alpha spectroscopy. The purpose of the confirmatory analysis was as a quality assurance measure, to evaluate the accuracy of the on-site results. Analytical methods were detailed in the SAP.

\subsubsection{Gamma Scanning}

Of the grid blocks, $10 \%$ were chosen randomly and scanned for hot particles. The scans were conducted using FIDLERs coupled to ratemeter/scalers in ratemeter mode. These walkover gamma scans were performed with the detectors held to within $10 \mathrm{~cm}$ of the coral surface. The detectors were swung in a serpentine manner over a $1-\mathrm{m}$ wide swath, and the scan rate did not exceed $465 \mathrm{~m}^{2}\left(5000 \mathrm{ft}^{2}\right)$ per person-hour. Scan rate minimum detectable concentration rates (MDCRs) were calculated on-site based on ambient gamma exposure rate ranges. In addition to calculating an action level based on MDCR, surveyors used the audio response of the instruments to screen for hot particles. The MARSSIM procedure for calculating scan MDC was used (EPA 1997). Scan ranges in counts were recorded on the field maps and in the project logbook. 
Table 1. Sample locations and depths

\begin{tabular}{|c|c|c|c|c|c|c|c|}
\hline Location No. & $\underset{(\mathrm{m})}{\mathrm{X}}$ & $\begin{array}{c}\mathrm{Y} \\
(\mathrm{m})\end{array}$ & $\begin{array}{c}Z \\
(\mathrm{ft})\end{array}$ & Location No. & $\underset{(\mathrm{m})}{\mathrm{X}}$ & $\begin{array}{c}Y \\
(\mathrm{~m})\end{array}$ & $\begin{array}{c}\mathrm{Z} \\
\text { (ft) }\end{array}$ \\
\hline 1 & 0.04 & 108.35 & 0.7 & 51 & 42.23 & 96.56 & 4.0 \\
\hline 2 & 0.41 & 84.77 & 3.1 & 52 & 43.73 & 56.38 & 2.7 \\
\hline 3 & -1.08 & 45.46 & 0.1 & 53 & 44.85 & 122.76 & 2.8 \\
\hline 4 & 1.91 & 21.88 & 3.2 & 54 & 45.22 & 65.11 & 2.8 \\
\hline 5 & -10.04 & 92.63 & 0.0 & 55 & 46.71 & 128.00 & 1.0 \\
\hline 6 & 10.87 & 116.21 & 3.4 & 56 & 47.83 & 2.22 & 3.4 \\
\hline 7 & 100.48 & 15.98 & 0.7 & 57 & 48.21 & 137.83 & 1.6 \\
\hline 8 & 104.59 & 42.19 & 2.1 & 58 & 49.70 & 74.94 & 3.0 \\
\hline 9 & 104.96 & 0.26 & 3.2 & 59 & -5.56 & 61.18 & 1.4 \\
\hline 10 & 109.44 & 38.69 & 1.3 & 60 & -5.94 & -6.95 & 2.0 \\
\hline 11 & -11.54 & 14.02 & 3.8 & 61 & 50.82 & 69.70 & 3.5 \\
\hline 12 & -11.91 & 40.22 & 1.1 & 62 & 51.19 & 12.05 & 3.9 \\
\hline 13 & 11.99 & 37.60 & 1.2 & 63 & 52.69 & 122.11 & 1.1 \\
\hline 14 & 12.36 & 131.93 & 2.2 & 64 & 53.81 & 22.53 & 2.0 \\
\hline 15 & -13.03 & -1.71 & 0.9 & 65 & 54.18 & 43.50 & 2.9 \\
\hline 16 & 13.85 & 91.75 & 2.9 & 66 & 55.67 & 3.32 & 3.2 \\
\hline 17 & 14.97 & 63.80 & 2.0 & 67 & 56.42 & 50.48 & 2.5 \\
\hline 18 & 15.35 & 6.16 & 3.7 & 68 & 56.79 & 6.81 & 1.8 \\
\hline 19 & 16.84 & 41.53 & 0.4 & 69 & 57.17 & 106.39 & 2.6 \\
\hline 20 & 17.96 & 99.18 & 3.5 & 70 & 58.66 & 27.77 & 2.5 \\
\hline 21 & 18.33 & 25.81 & 2.5 & 71 & 59.78 & 90.66 & 3.2 \\
\hline 22 & 19.83 & 127.13 & 2.7 & 72 & 6.01 & 110.97 & 1.0 \\
\hline 23 & -2.57 & 29.74 & 4.0 & 73 & 6.39 & -9.57 & 2.6 \\
\hline 24 & -2.95 & 87.39 & 2.2 & 74 & 60.15 & -3.67 & 2.4 \\
\hline 25 & 20.58 & 79.96 & 3.6 & 75 & 62.77 & 116.87 & 2.2 \\
\hline 26 & 20.95 & -10.88 & 0.2 & 76 & 63.14 & 59.22 & 2.8 \\
\hline 27 & 21.32 & 135.86 & 0.5 & 77 & 65.75 & 46.12 & 0.9 \\
\hline 28 & 22.82 & 10.09 & 0.1 & 78 & 66.13 & 114.25 & 4.0 \\
\hline 29 & 23.94 & 72.98 & 3.3 & 79 & 67.62 & 74.07 & 0.7 \\
\hline 30 & 24.31 & 120.14 & 3.7 & 80 & 68.74 & 140.45 & 3.0 \\
\hline 31 & 25.80 & 57.25 & 0.2 & 81 & 69.12 & 82.80 & 0.8 \\
\hline 32 & 26.92 & 52.01 & 2.3 & 82 & 70.61 & 98.52 & 2.4 \\
\hline 33 & 27.30 & -5.64 & 2.2 & 83 & 71.73 & 19.91 & 3.4 \\
\hline 34 & 28.79 & 104.42 & 0.2 & 84 & 72.10 & 67.08 & 1.7 \\
\hline 35 & 29.91 & 4.85 & 0.4 & 85 & 73.60 & 4.19 & 1.2 \\
\hline 36 & 3.03 & 16.64 & 2.7 & 86 & 74.72 & -1.05 & 1.2 \\
\hline 37 & 3.40 & 100.49 & 0.5 & 87 & 75.09 & 129.97 & 3.6 \\
\hline 38 & 30.28 & 88.70 & 3.1 & 88 & 76.58 & 51.36 & 0.3 \\
\hline 39 & 31.78 & 32.80 & 2.6 & 89 & 77.70 & 93.28 & 1.4 \\
\hline 40 & 32.52 & 103.55 & 0.8 & 90 & 78.08 & 35.63 & 0.2 \\
\hline 41 & 32.90 & 59.87 & 2.6 & 91 & -8.55 & 76.91 & 0.3 \\
\hline 42 & 33.27 & 17.95 & 3.6 & 92 & 8.63 & -2.58 & 1.6 \\
\hline 43 & 34.76 & 80.84 & 1.2 & 93 & 80.32 & 15.11 & 3.2 \\
\hline 44 & 36.26 & 49.39 & 2.3 & 94 & 81.06 & 71.01 & 2.5 \\
\hline 45 & 38.87 & 28.43 & 1.4 & 95 & 85.54 & 39.57 & 1.5 \\
\hline 46 & 39.24 & 112.28 & 1.0 & 96 & 87.04 & 23.84 & 3.5 \\
\hline 47 & -4.07 & 21.00 & 1.4 & 97 & 9.00 & 95.25 & 3.8 \\
\hline 48 & 4.89 & 69.04 & 1.1 & 98 & 9.37 & 53.32 & 0.3 \\
\hline 49 & 40.74 & 33.67 & 2.5 & 99 & 90.03 & 8.12 & 1.5 \\
\hline \multirow[t]{4}{*}{50} & 41.86 & 75.60 & 1.7 & 100 & 92.64 & 34.32 & 1.1 \\
\hline & & & & 101 & 95.63 & 55.29 & 3.1 \\
\hline & & & & 102 & 96.00 & 31.70 & 0.3 \\
\hline & & & & 103 & 98.99 & 47.43 & 1.3 \\
\hline
\end{tabular}


Table 2. Instrumentation parameters

\begin{tabular}{|c|c|c|c|c|c|c|c|}
\hline Instrument & Detector & $\begin{array}{c}\text { Calibration } \\
\text { nuclide }\end{array}$ & $\begin{array}{c}\text { Active area of } \\
\text { detector } \\
(\mathrm{cm})^{2}\end{array}$ & $\begin{array}{l}\text { Instrument } \\
\text { efficiency } \\
(\%)\end{array}$ & $\begin{array}{c}\text { Minimum detectable } \\
\text { concentration } \\
\left(\mathrm{dpm} / 100 \mathrm{~cm}^{2}\right)\end{array}$ & $\begin{array}{l}\text { Type of } \\
\text { radiation }\end{array}$ & $\begin{array}{l}\text { Calibration geometry } \\
\text { and spacing }\end{array}$ \\
\hline $\begin{array}{l}\text { Ludlum Data Logger } \\
\text { Model } 2360 \\
\text { Ludlum Measurements, Inc. } \\
\text { Sweetwater, TX }\end{array}$ & $\begin{array}{l}\text { Ludlum Plastic } \\
\text { Scintillator } \\
\text { Model 43-89 } \\
\text { Ludlum, } \\
\text { Sweetwater, TX }\end{array}$ & $\begin{array}{l}{ }^{239} \mathrm{Pu} \\
\mathrm{Sr} /^{90} \mathrm{Y}\end{array}$ & 126 & $\begin{array}{l}9.0-{ }^{239} \mathrm{Pu} \\
27.0-\mathrm{Sr} /{ }^{90} \mathrm{Y} \\
\text { (distributed) } \\
16.0-{ }^{239} \mathrm{Pu} \\
48.0-\mathrm{Sr}{ }^{90} \mathrm{Y} \text { (point } \\
\text { source) }\end{array}$ & $\begin{array}{l}65(\alpha) \\
250(\beta) \text { (distributed) } \\
38(\alpha) \\
138(\beta) \text { (point } \\
\quad \text { sourcc) }\end{array}$ & Alpha, beta & $\begin{array}{l}\text { Distributed }^{a} \text { and point } \\
\text { source geometries, } \\
\text { 1/4-in. spacing }\end{array}$ \\
\hline $\begin{array}{l}\text { Ludlum Model } 2221 \\
\text { Ratemeter-Scaler } \\
\text { Ludlum Measurements, Inc. } \\
\text { Sweetwater, TX }\end{array}$ & $\begin{array}{l}\text { FIDLER } \\
\text { G-5 } \\
\text { Bicron NE } \\
\text { Solon, OH }\end{array}$ & ${ }^{241} \mathrm{Am}$ & 300 & $25.0-241 \mathrm{Am}$ & $\sim 65 \mathrm{nCi}$ & Gamma & Point source geometry \\
\hline $\begin{array}{l}\text { NS } 2000 \text { R Multi-Channel } \\
\text { Analyzer } \\
\text { American Nuclear Systems } \\
\text { Oak Ridge, TN }\end{array}$ & ANS FIDLERs & ${ }^{241} \mathrm{Am}$ & 300 & 48 & $<1$ & Gamma & 3-mm Distributed coral \\
\hline
\end{tabular}

${ }^{a}$ ANS $=$ American Nuclear Systems. 


\section{RESULTS}

Results of the on-site analysis of the soil samples are shown in Table 3 and detailed in Appendix B. Results of gamma scanning are shown in Fig. 4. Results of confirmatory (QC) analysis are provided in Tables 4-6, Fig. 5, and detailed in Appendix C. Table 7 provides results of fixed-point measurements taken at grid point locations to supplement the gamma scanning data.

The total TRU activity results in Table 3 are sorted from high to low activity. Nine samples exceeded the soil screening criteria established by the DTRA. These samples were collected from various random locations and depths within the pile (Fig. 3) and indicate that there is no particular pattern or boundary of contamination in the pile.

After sample analysis on site, samples were shipped to Oak Ridge, Tennessee, for confirmatory analysis as a QC measure. The highest 32 results from on-site analysis were selected for confirmatory analysis, and they constitute approximately $30 \%$ of total results, as planned. Results of this analysis are compared with the on-site analysis in Tables 5 and 6 and Fig. 5, and they show that the relative percent difference (RPD) for the majority ( 25 out of 32 ) of samples was $<75 \%$, which shows a fair agreement between the two values. Fourteen (a little less than one-half) have an RPD less than $60 \%$, which indicates that the two values generally agree. With the exception of sample 28 , the RPDs that were more than $100 \%$ (poor agreement) were results below the soil screening value of 13.5 , and not significant to the evaluation. Figure 5 further demonstrates that the QC results were nearly systematically lower than the on-site results. This issue is not significant to the conclusions, but should be investigated prior to future surveys. Seven of the QC results exceed the soil-screening limit. The on-site analytical results are considered reliable and suitable for the statistical tests discussed in the following section. The higher RPDs of the on-site and QC analyses could be due to several factors including (1) different reference material used for calculating efficiency and (2) difference in position of contaminants within the petri dish from shipping and settling.

Further QC was provided by the analysis of four samples by radiochemistry, shown in Table 5. The samples were selected in a bias manner and represent high and low RPDs. Three of the four results of the radiochemical analysis were lower than the on-site measurements. The sample aliquot for radiochemical analysis is small $(\sim 10 \mathrm{~g})$ compared to the sample counted on the gamma spectroscopy systems, and it is possible that contamination detected in the gamma specification sample is not contained in the aliquot for the radiochemical analysis. Because of the heterogeneous nature of the contaminant and the small sample size $(n=4)$, no conclusions should be drawn from the radiochemical data, other than the basic trend of lower results. The ratio of TRU/Am, as stated by ANS (6.17) predicted slightly higher results than those observed in the radiochemical analysis (Table 5). However, RPDs were calculated for comparative purposes only (Table 6).

Results of the gamma scan on $10 \%$ of the grid blocks (Fig. 4) show gamma flux to range from 30 to $1100 \mathrm{cpm}$, averaging $260 \mathrm{cpm}$. To supplement the gamma scan data, 124 fixed-point measurements were collected at grid intersections and are presented in Tables 5 and 6 . Fixed-point background measurements were collected in four locations and ranged from 276 to $388 \mathrm{cpm}$. In comparison to this threshold range, fixed-point measurements ranged from 112 to $652 \mathrm{cpm}$, with a mean average of 322 and a median of 297 . These averages are well within the threshold range. The elevated gamma fluence detected from 388 to $652 \mathrm{cpm}$ is consistent with previous scans at JA where locations of high gamma fluence were sampled and were not explained by total TRU activity results or variation in background radionuclides (ORNL 1998). The survey team did not detect any hot particles, which range orders of magnitude higher $(220,000$ to $100,000 \mathrm{cpm})$ than the maximum scan measurement of $1100 \mathrm{cpm}$. 
Table 3. Total TRUs in coral samples from clean storage pile

\begin{tabular}{|c|c|c|c|c|c|c|c|c|c|}
\hline Location & ANS No. & $\begin{array}{c}\text { Date } \\
\text { counted }\end{array}$ & Time & $\begin{array}{l}\text { Weight } \\
(\mathrm{g})\end{array}$ & $\begin{array}{l}\text { Gross } \\
\text { activity } \\
\text { (pCi) }\end{array}$ & Sigma & $\begin{array}{l}\text { Specific } \\
\text { activity } \\
(\mathrm{pCi} / \mathrm{g})\end{array}$ & Sigma & $\underset{(\mathrm{pCi} / \mathrm{g})}{\mathrm{MDC}}$ \\
\hline & $\mathrm{C} 000034$ & $3-\operatorname{Jan} 99^{\circ}$ & $11: 09$ & & 11259.9 & 2772 & 125.9 & 31 & 0.1 \\
\hline & $\mathrm{C} 000008$ & $21-\operatorname{Jan}-99$ & $14: 57$ & & 3056.9 & 124. & 37.8 & 15 & 0.1 \\
\hline & $\mathrm{C} 000038$ & 25-Jan-99 & $7: 56$ & & 3159.1 & 140.3 & 32.3 & 12 & 0.1 \\
\hline & $\mathrm{C} 000050$ & $23-J_{a n}-99$ & $16: 54$ & & 1973.6 & 106.0 & 22.4 & & 0.1 \\
\hline & $\mathrm{C} 000005$ & $22-\operatorname{Tan}-99$ & $9: 57$ & & 1408.5 & 95.2 & 16.0 & 1. & 0.1 \\
\hline & $\mathrm{C} 000047$ & $23-\tan -92$ & $15: 53$ & & 1474.7 & 975 & 15.5 & & 0.1 \\
\hline & $\mathrm{C} 000008$ & $24-\operatorname{Jan}-99$ & $12: 41$ & & 1382.2 & 95. & 15.4 & 1 & 0.1 \\
\hline & $\mathrm{C} 000053$ & $25-\mathrm{Jan}-99$ & $13: 48$ & & 1354.8 & 113. & 15.1 & 1. & 0.1 \\
\hline & $\mathrm{C} 000007$ & $-21-\operatorname{Jan}-99$ & $14: 36$ & & 1160.2 & 191. & 13.7 & 1 & 0.1 \\
\hline & $\mathrm{C} 000003$ & $21-\mathrm{Jan} 99^{\circ}$ & $13: 20$ & & 902.1 & 87 & 12.2 & 1. & 0.1 \\
\hline & $\mathrm{C} 000041$ & $25-\operatorname{Jan}-90$ & $8: 50$ & & 980.6 & 107 & 11.0 & & 0.1 \\
\hline & $\mathrm{C} 000010$ & $21-\operatorname{Jan}-99$ & $15: 35$ & & 874.2 & 86 & 10.5 & & 0.1 \\
\hline & C000009 & $21-\operatorname{Tan}-9$ & $15: 16$ & & 863.4 & 86 & 9.9 & 1.0 & 0.1 \\
\hline & $\mathrm{C} 000014$ & $22-\tan -99$ & $13: 57$ & & 832.2 & L & 9.9 & 1.0 & 0.1 \\
\hline 3 & $\mathrm{C} 000022$ & $22-\tan -99$ & $16: 51$ & & 892.4 & 8 & 9.9 & 1.0 & 0.1 \\
\hline 5 & $\mathrm{C} 000051$ & $23-J a n-99$ & $17: 10$ & & 864 & 8 & 9.4 & 10 & 0.1 \\
\hline & C000049 & $23-\operatorname{Jan}-99$ & $16: 34$ & & 775.8 & 86 & 8.6 & 11.0 & 0.1 \\
\hline & $\mathrm{C} 000011$ & 24- $\operatorname{an}-99$ & $13: 35$ & & 758.6 & & 8.5 & 11 & 0.1 \\
\hline & $\mathrm{C} 000021$ & 24-Jan-99 & $17: 14$ & & 771.5 & 10. & 8.4 & 0 & 0.1 \\
\hline & $\mathrm{C} 000007$ & $22-\operatorname{san}-99$ & $10: 42$ & & 772 & & 8.2 & 0 & 0.1 \\
\hline & $\mathrm{C} 000014$ & $24-\operatorname{Jan}-99$ & $14: 59$ & & 797.3 & & 8.2 & 0. & 0.1 \\
\hline & $\mathrm{C} 000015$ & 21 Jan -99 & $17: 29$ & & 684.9 & & 7.9 & 1. & 0.1 \\
\hline & $\mathrm{C} 000015$ & $=22-\mathrm{Jan}-99$ & $14: 17$ & & 701.1 & & 7.9 & 109 & 0.1 \\
\hline & $\mathrm{C} 000003$ & $24-J a n-99$ & $11: 09$ & & 711.3 & & 7.9 & 0. & 0.1 \\
\hline & $\mathrm{C} 000029$ & $23-\operatorname{Jan}-99$ & $9: 20$ & & 662.3 & & 7.9 & 11. & 0.1 \\
\hline & $\mathrm{C} 000025$ & $22-1 \mathrm{an}-99$ & $17: 44$ & & 739.8 & & 7.7 & 09 & 0.1 \\
\hline & $\mathrm{C} 000045$ & $23-\operatorname{Jan}-99$ & $15: 13$ & & 691.9 & & 7.6 & 09 & 0.1 \\
\hline & $\mathrm{C} 000043$ & $25-\sqrt{a n}-99$ & $9: 33$ & & 707.5 & 104 & 7.5 & 11 & 0.1 \\
\hline & $\mathrm{C} 000008$ & $22-\operatorname{Jan}-99$ & $11: 02$ & & 666.6 & & 7.4 & $0 \%$ & 0.1 \\
\hline & $\mathrm{C} 000042$ & $23-\operatorname{Jan}-99^{\circ}$ & $14: 22$ & & 683.3 & & 7.3 & 00 & 0.1 \\
\hline & $\mathrm{C} 000013$ & $22-\operatorname{an} 99^{\circ}$ & $13: 28$ & & 690.3 & $=$ & 7.2 & 10 & 0.1 \\
\hline 3 & $\mathrm{C} 000014$ & $21-\mathrm{Jan}-99^{\circ}$ & $17: 06$ & & 654.8 & & 7.1 & 0. & 0.1 \\
\hline 2 & $\mathrm{C} 000020$ & $22 \operatorname{Tan}-99^{\circ}$ & $15: 55$ & & 752.7 & & 7.1 & 0. & 0.1 \\
\hline 8 & $\mathrm{C} 000032$ & $24-\operatorname{Jan}-99$ & $21: 01$ & Ui & 631.7 & & 7.0 & 0 & 0.1 \\
\hline 8 & $\mathrm{C} 000030$ & $24 \operatorname{Jan}-99^{\circ}$ & $20: 28$ & & 616.6 & & 6.7 & 0 & 0.1 \\
\hline 10 & $\mathrm{C} 000052$ & $25-\operatorname{Jan}-99$ & $13: 31$ & -90 & 602.1 & 03 & 6.7 & 1. & 0.1 \\
\hline 8 & $\mathrm{C} 000031$ & $24-\operatorname{Jan}-99$ & $20: 44$ & o & 575.8 & & 6.6 & 0. & 0.1 \\
\hline 5 & $\mathrm{C} 000003$ & 22-Jan-99: & $9: 14$ & 86 & 539.8 & & 6.3 & 0. & 0.1 \\
\hline 5 & $\mathrm{C} 000041$ & $23-\mathrm{Jan}-99^{\circ}$ & $14: 05$ & 90 & 599.4 & 83 & 6.3 & 0.9 & 0.1 \\
\hline 94 & $\mathrm{C} 000046$ & $25-\mathrm{Jan}-99^{\circ}$ & $10: 37$ & & 533.3 & & 6.3 & 1.2 & 0.1 \\
\hline 1 & $\mathrm{C} 000044$ & $23-\mathrm{Jan}-99^{\circ}$ & $14: 56$ & & 584.4 & 83 & 6.2 & 0.9 & 0.1 \\
\hline 6 & $\mathrm{C} 000017$ & 24 Jan-99 & $15: 59$ & & 603.7 & 83. & 6.2 & 0.9 & 0.1 \\
\hline 1 & $\mathrm{C} 000015$ & $24-\operatorname{Jan}-99$ & $15: 16$ & & 517.7 & 818 & 6.1 & 210 & 0.1 \\
\hline 84 & $\mathrm{C} 000033$ & $23-\mathrm{J}$ an -99 & $10: 32$ & & 630.1 & & 6.1 & 0.8 & 0.1 \\
\hline 6 & $\mathrm{C} 000013$ & $24 \operatorname{Jan}-99$ & $14: 42$ & & 500.5 & & 6.0 & 1.0 & 0.1 \\
\hline 10 & $\mathrm{C} 000028$ & $24 \operatorname{Jan}-99$ & $19: 55$ & & 511.3 & $81 \mathrm{~T}$ & 6.0 & 10 & 0.1 \\
\hline 120 & $\mathrm{C} 000005$ & 24 Jan-99: & $11: 44$ & -92 & 541.4 & & 5.9 & 109 & 0.1 \\
\hline 3, & $\mathrm{C} 000043$ & 23-Jan -99 & $14: 38$ & -92 & 537.1 & 82.4 & 5.8 & 0.9 & 0.1 \\
\hline 49 & $\mathrm{C} 000018$ & $22-\operatorname{lan}-99$ & $15: 20$ & 101 & 587.1 & -818 & 5.8 & 20.8 & 0.1 \\
\hline
\end{tabular}


Table 3. (continued)

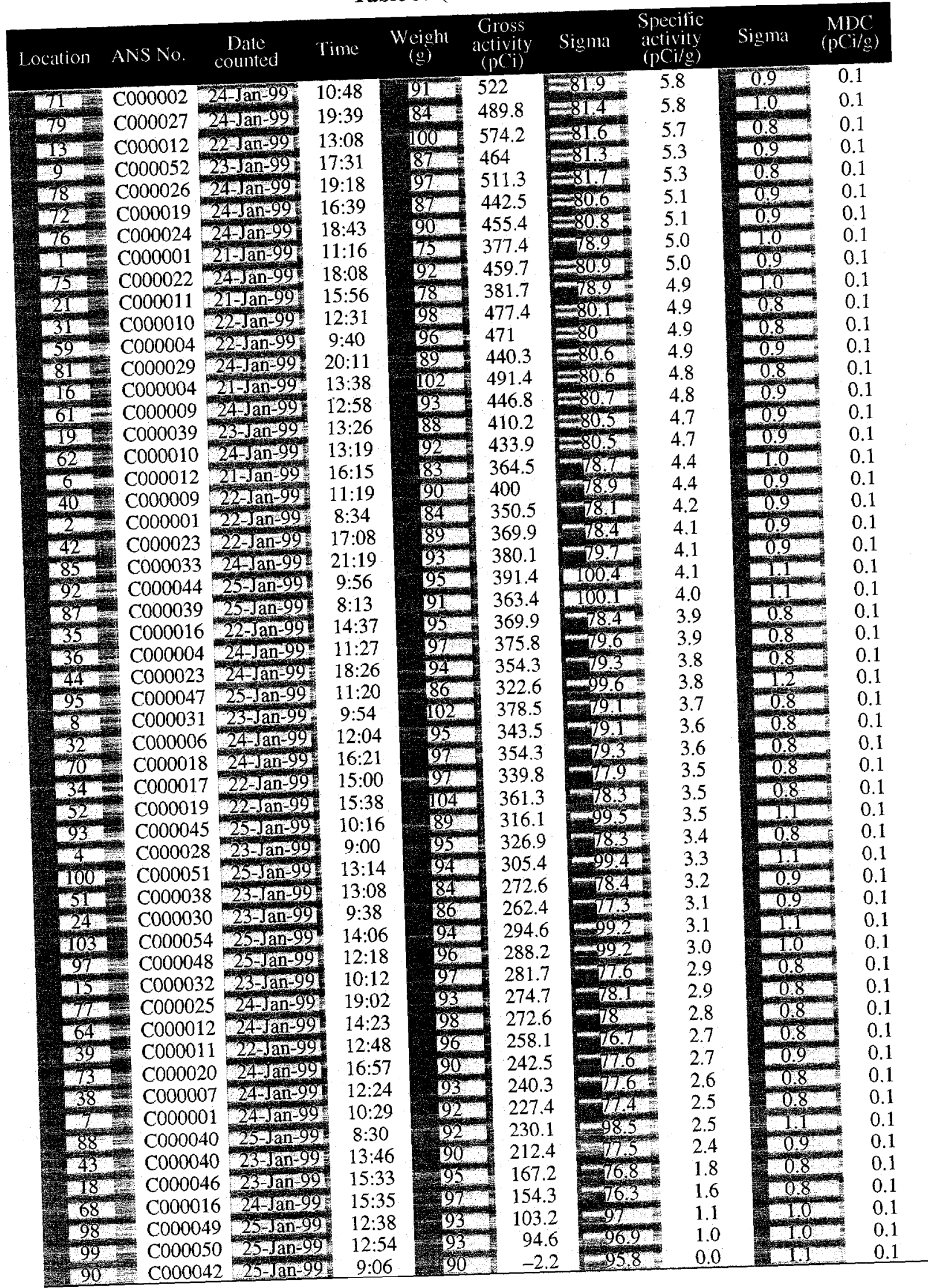




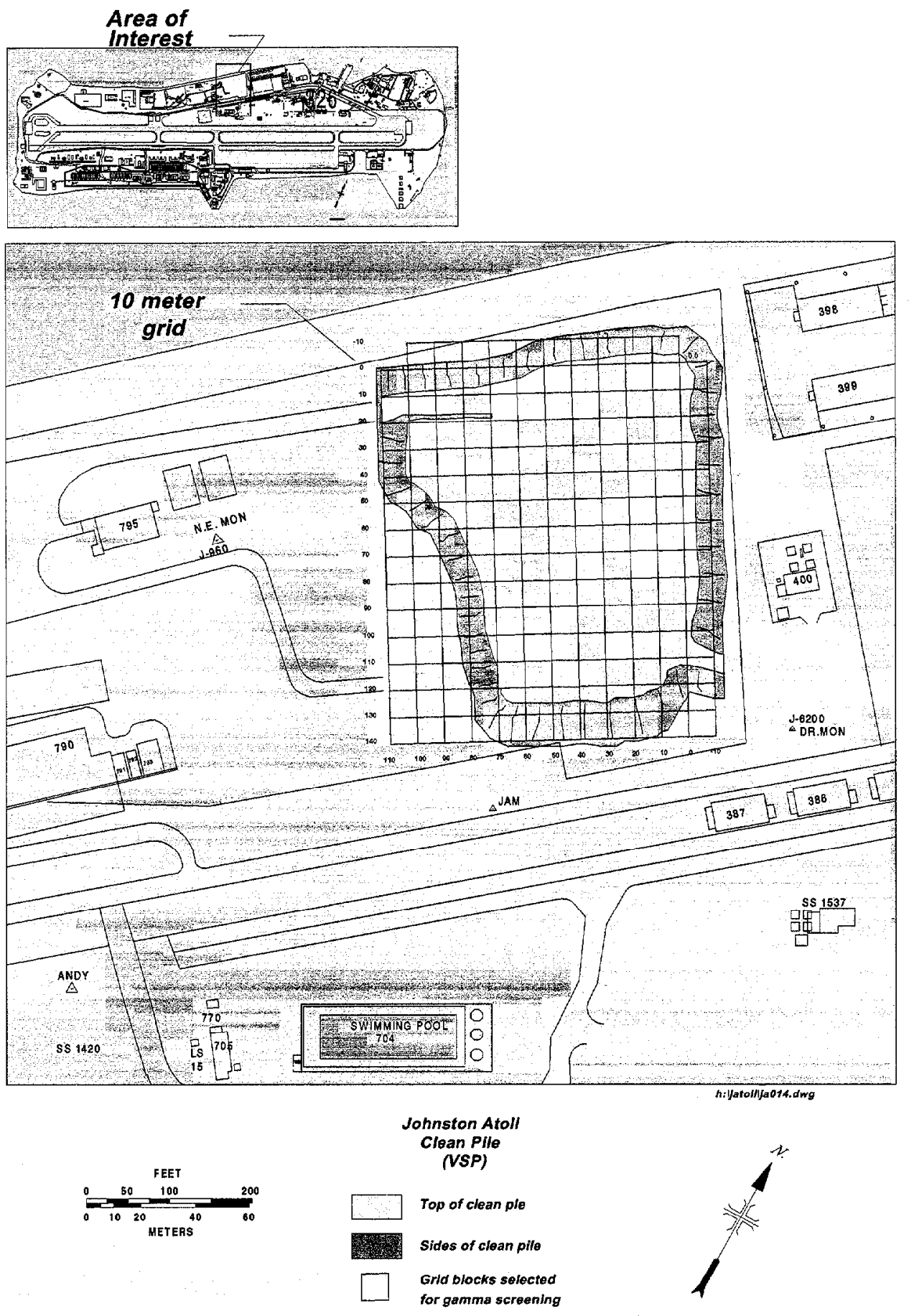

Fig. 4. Locations of blocks selected for surface gamma scan. 
Table 4. Results of confirmatory analysis for total TRU

\begin{tabular}{cccccr}
\hline Location & ANS No. & Date & $\begin{array}{c}\text { ANS specific } \\
\text { activity }^{a} \\
(\mathrm{pCi} / \mathrm{g})\end{array}$ & $\begin{array}{c}\text { QC specific } \\
\text { activity }^{b} \\
(\mathrm{pCi} / \mathrm{g})\end{array}$ & $\begin{array}{r}\text { Relative } \\
\text { percent } \\
\text { difference }\end{array}$ \\
\hline 57 & C000034 & 23 January 1999 & 125.9 & 98.7 & 24.2 \\
22 & C000008 & 21 January 1999 & 37.8 & 26.5 & 35.0 \\
86 & C000038 & 25 January 1999 & 32.3 & 38.8 & -18.4 \\
58 & C000050 & 23 January 1999 & 22.4 & 18.5 & 19.0 \\
28 & C000005 & 22 January 1999 & 16 & 1.6 & 163.5 \\
10 & C000047 & 23 January 1999 & 15.5 & 11.7 & 27.7 \\
60 & C000008 & 24 January 1999 & 15.4 & 8.6 & 56.2 \\
102 & C000053 & 25 January 1999 & 15.1 & 19.1 & -23.5 \\
23 & C000007 & 21 January 1999 & 13.7 & 28.9 & -71.6 \\
25 & C000003 & 21 January 1999 & 12.2 & 6.7 & 57.0 \\
89 & C000041 & 25 January 1999 & 11 & 5.1 & 71.8 \\
14 & C000010 & 21 January 1999 & 10.5 & 5.4 & 62.6 \\
20 & C000009 & 21 January 1999 & 9.9 & 2.7 & 112.3 \\
30 & C000014 & 22 January 1999 & 9.9 & 4.6 & 72.5 \\
33 & C000022 & 22 January 1999 & 9.9 & 8.6 & 13.6 \\
53 & C000051 & 23 January 1999 & 9.4 & 4.9 & 62.2 \\
54 & C000049 & 23 January 1999 & 8.6 & 8.6 & -0.4 \\
63 & C000011 & 24 January 1999 & 8.5 & 21.5 & -87.0 \\
74 & C000021 & 24 January 1999 & 8.4 & 8.0 & 4.6 \\
47 & C000007 & 22 January 1999 & 8.2 & 2.0 & 120.4 \\
67 & C000014 & 24 January 1999 & 8.2 & 3.8 & 72.7 \\
12 & C000015 & 21 January 1999 & 7.9 & 5.6 & 32.7 \\
26 & C000015 & 22 January 1999 & 7.9 & 6.7 & 15.1 \\
41 & C000003 & 24 January 1999 & 7.9 & 6.0 & 26.5 \\
65 & C000029 & 23 January 1999 & 7.9 & 5.3 & 38.1 \\
50 & C000025 & 22 January 1999 & 7.7 & 3.4 & 76.1 \\
27 & C000045 & 23 January 1999 & 7.6 & 4.6 & 47.3 \\
91 & C000043 & 25 January 1999 & 7.5 & 3.2 & 80.1 \\
46 & C000008 & 22 January 1999 & 7.4 & 3.4 & 72.6 \\
56 & C000042 & 23 January 1999 & 7.3 & 1.9 & 114.8 \\
45 & C000013 & 22 January 1999 & 7.2 & 2.8 & 85.1 \\
3 & C000014 & 21 January 1999 & 7.1 & 3.7 & 61.4 \\
\hline
\end{tabular}

${ }^{a}$ Value from on-site radioanalytical laboratory.

${ }^{b}$ Value from QC third party analyzed in Oak Ridge, Tennessee. 
Table 5. Results of radiochemistry

\begin{tabular}{|c|c|c|c|c|c|c|}
\hline $\begin{array}{l}\text { Sample } \\
\text { ID }\end{array}$ & Nuclide & Result & Uncertainty & Units & $\begin{array}{l}\text { Predicted } \\
\text { TRU result }\end{array}$ & $\begin{array}{c}\text { Observed } \\
\text { TRU }{ }^{241} \text { Am ratio }\end{array}$ \\
\hline 026 & ${ }^{241} \mathrm{Am}$ & 1.1 & 0.11 & $\mathrm{pCi} / \mathrm{g}$ & & \\
\hline 026 & ${ }^{243 / 244} \mathrm{Cu}$ & 0.004 & 0.009 & $\mathrm{pCi} / \mathrm{g}$ & & \\
\hline 026 & ${ }^{238} \mathrm{Pu}$ & 0.088 & 0.022 & $\mathrm{pCi} / \mathrm{g}$ & & \\
\hline \multirow[t]{2}{*}{026} & ${ }^{239 / 240} \mathrm{Pu}$ & 5.3 & 0.55 & $\mathrm{pCi} / \mathrm{g}$ & & \\
\hline & Total & 6.49 & & & 6.79 & 5.90 \\
\hline 028 & ${ }^{241} \mathrm{Am}$ & 0.4 & 0.063 & $\mathrm{pCi} / \mathrm{g}$ & & \\
\hline 028 & ${ }^{243 / 244} \mathrm{Cu}$ & -0.004 & 0.008 & $\mathrm{pCi} / \mathrm{g}$ & & \\
\hline 028 & ${ }^{238} \mathrm{Pu}$ & 0.026 & 0.013 & $\mathrm{pCi} / \mathrm{g}$ & & \\
\hline \multirow[t]{2}{*}{028} & ${ }^{239 / 240} \mathrm{Pu}$ & 2 & 0.22 & $\mathrm{pCi} / \mathrm{g}$ & & \\
\hline & Total & 2.43 & & & 2.47 & 6.06 \\
\hline 058 & ${ }^{241} \mathrm{Am}$ & 1.9 & 0.19 & $\mathrm{pCi} / \mathrm{g}$ & & \\
\hline 058 & ${ }^{243 / 244} \mathrm{Cu}$ & -0.005 & 0.006 & $\mathrm{pCi} / \mathrm{g}$ & & \\
\hline 058 & ${ }^{238} \mathrm{Pu}$ & 0.14 & 0.032 & $\mathrm{pCi} / \mathrm{g}$ & & \\
\hline \multirow[t]{2}{*}{058} & ${ }^{239 / 240} \mathrm{Pu}$ & 9.6 & 1 & $\mathrm{pCi} / \mathrm{g}$ & & \\
\hline & Total & 11.64 & & & 11.72 & 6.12 \\
\hline 086 & ${ }^{241} \mathrm{Am}$ & 0.75 & 0.094 & $\mathrm{pCi} / \mathrm{g}$ & & \\
\hline 086 & ${ }^{243 / 244} \mathrm{Cu}$ & -0.002 & 0.007 & $\mathrm{pCi} / \mathrm{g}$ & & \\
\hline 086 & ${ }^{238} \mathrm{Pu}$ & 0.071 & 0.021 & $\mathrm{pCi} / \mathrm{g}$ & & \\
\hline \multirow[t]{2}{*}{086} & ${ }^{239 / 240} \mathrm{Pu}$ & 4 & 0.42 & $\mathrm{pCi} / \mathrm{g}$ & & \\
\hline & Total & 4.82 & & & 4.63 & 6.43 \\
\hline
\end{tabular}

Table 6. Radiochemistry vs gamma spectral results (total TRU in $\mathrm{pCi} / \mathrm{g}$ )

\begin{tabular}{crrrrrr}
\hline Sample ID & ANS & QC & ASO & RPD $^{a}$ & RPD $^{b}$ & RPD $^{c}$ \\
\hline 026 & 7.9 & 6.8 & 6.5 & 15.2 & 19.6 & 4.4 \\
028 & 16.0 & 1.6 & 2.4 & 163.5 & 147.4 & -40.6 \\
086 & 32.3 & 38.9 & 4.8 & -18.5 & 148.1 & 155.9 \\
058 & 22.4 & 18.5 & 11.6 & 19.0 & 63.3 & 45.6 \\
\hline
\end{tabular}

$\mathrm{RPD}=$ relative percent difference $=100 \times 2 \times \mathrm{lx}_{1}-\mathrm{x}_{2} 1 /\left(\mathrm{x}_{1}+\mathrm{x}_{2}\right)$.

${ }^{a}$ American Nuclear Systems (ANS)/QC (gamma spec.).

${ }^{b}$ ANS/Analytical Services Organization (ASO) (on-site vs radiochemistry).

${ }^{c} \mathrm{QC} / \mathrm{ASO}$ [Oak Ridge National Laboratory (ORNL) QC vs radiochemistry]. 

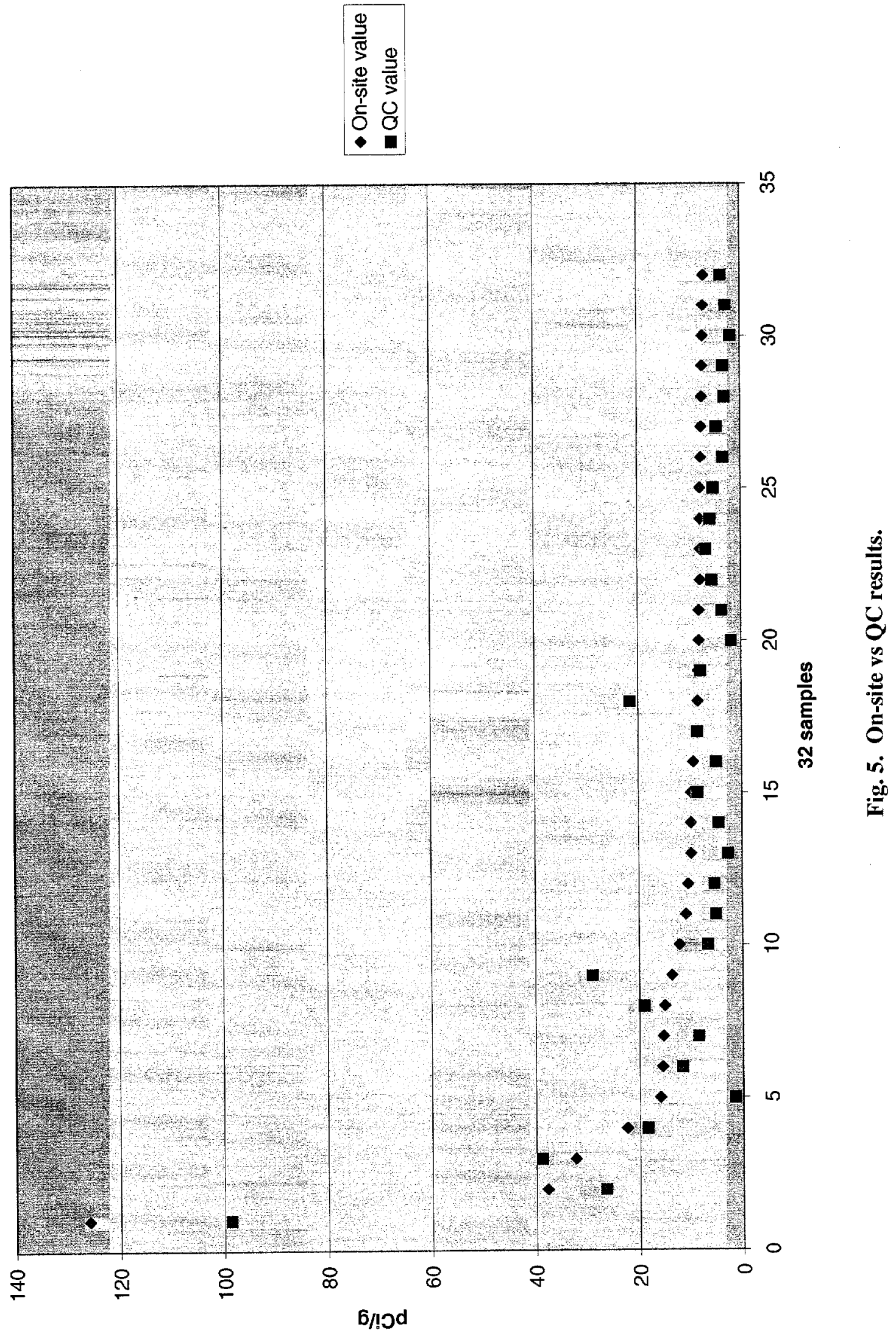
Table 7. Fixed point measurements at grid point locations

\begin{tabular}{|c|c|c|c|c|c|c|c|c|}
\hline $\mathrm{X}$-axis & $\mathrm{Y}$-axis & $\mathrm{cpm}$ & $\mathrm{X}$-axis & $Y$-axis & $\mathrm{cpm}$ & $\mathrm{X}$-axis & $Y$-axis & cpm \\
\hline 0 & 0 & 160 & 70 & 60 & 330 & 20 & 50 & 342 \\
\hline 0 & 10 & 626 & 70 & 50 & 170 & 20 & 40 & 208 \\
\hline 0 & 20 & 364 & 70 & 40 & 238 & 20 & 30 & 304 \\
\hline 0 & 30 & 350 & 70 & 30 & 204 & 20 & 20 & 274 \\
\hline 0 & 40 & 448 & 70 & 20 & 394 & 20 & 10 & 140 \\
\hline 0 & 50 & 328 & 70 & 10 & 520 & 20 & 0 & 230 \\
\hline 0 & 60 & 420 & 80 & 10 & 380 & 40 & 0 & 348 \\
\hline 0 & 70 & 552 & 90 & 10 & 484 & 40 & 10 & 164 \\
\hline 0 & 80 & 320 & 100 & 10 & 630 & 40 & 20 & 240 \\
\hline 0 & 90 & 470 & 110 & 10 & 622 & 40 & 30 & 178 \\
\hline 30 & 120 & 152 & 100 & 20 & 398 & 40 & 40 & 274 \\
\hline 30 & 110 & 318 & 100 & 30 & 426 & 40 & 50 & 336 \\
\hline 30 & 100 & 552 & 100 & 40 & 226 & 40 & 60 & 258 \\
\hline 30 & 90 & 488 & 70 & 40 & 450 & 40 & 70 & 256 \\
\hline 30 & 80 & 312 & 70 & 40 & 402 & 40 & 80 & 152 \\
\hline 30 & 70 & 504 & 50 & 50 & 474 & 40 & 90 & 282 \\
\hline 30 & 60 & 382 & 30 & 50 & 344 & 40 & 100 & 252 \\
\hline 30 & 50 & 238 & 30 & 40 & 600 & 40 & 110 & 188 \\
\hline 30 & 30 & 584 & 30 & 30 & 380 & 40 & 120 & 220 \\
\hline 30 & 20 & 368 & 30 & 20 & 544 & 60 & 120 & 292 \\
\hline 30 & 10 & 516 & 10 & 0 & 198 & 60 & 110 & 336 \\
\hline 30 & 0 & 320 & 10 & 10 & 240 & 60 & 100 & 196 \\
\hline 50 & 0 & 652 & 10 & 20 & 248 & 60 & 90 & 274 \\
\hline 50 & 10 & 452 & 10 & 30 & 204 & 60 & 180 & 162 \\
\hline 50 & 20 & 266 & 10 & 40 & 262 & 60 & 70 & 222 \\
\hline 50 & 30 & 464 & 10 & 50 & 198 & 60 & 60 & 198 \\
\hline 50 & 40 & 382 & 10 & 60 & 304 & 60 & 50 & 202 \\
\hline 50 & 50 & 676 & 10 & 70 & 142 & 60 & 40 & 318 \\
\hline 50 & 60 & 394 & 10 & 80 & 258 & 60 & 30 & 304 \\
\hline 50 & 80 & 378 & 10 & 90 & 280 & 60 & 20 & 184 \\
\hline 50 & 90 & 576 & 10 & 100 & 234 & 60 & 10 & 204 \\
\hline 50 & 100 & 338 & 10 & 110 & 300 & 80 & 20 & 182 \\
\hline 50 & 110 & 400 & 20 & 110 & 172 & 80 & 30 & 234 \\
\hline 50 & 120 & 242 & 20 & 100 & 280 & 80 & 40 & 176 \\
\hline 70 & 110 & 592 & 20 & 90 & 252 & 80 & 50 & 264 \\
\hline 70 & 100 & 532 & 20 & 80 & 134 & 80 & 60 & 196 \\
\hline 70 & 90 & 380 & 20 & 70 & 300 & 90 & 50 & 318 \\
\hline 70 & 80 & 294 & 20 & 60 & 112 & 90 & 40 & 242 \\
\hline 70 & 70 & 564 & 20 & 30 & 228 & 90 & 30 & 192 \\
\hline 40 & 0 & 286 & 20 & 10 & 138 & 90 & 20 & 228 \\
\hline 40 & 20 & 124 & 10 & 0 & 338 & 60 & 10 & 166 \\
\hline
\end{tabular}




\section{STATISTICAL EVALUATION OF DATA}

Summary statistics are presented in Table 8 . The statistical approach was a nonparametric equation for estimating one-sided upper confidence limits on percentiles (quantiles) and was described in the SAP (ORNL 1998a). The minimum sample size needed to use this test was 99. The null hypothesis presented in Sect. 2.1 cannot be rejected using a sample size of $n=103$ (results in Table 3). This is because the one-sided upper 95\% confidence limit for the 97th percentile is greater than the 13.5-pCi/g DCGL (Fig. 6). Therefore, the original goal of demonstrating that $97 \%$ of the pile is clean at a $95 \%$ confidence level was not achieved. However, the test is able to show that $88 \%$ of the pile can be projected to be below the $13.5-\mathrm{pCi} / \mathrm{g}$ limit at the $90 \%$ confidence level. Accordingly, the nonparametric one-sided upper $95 \%$ confidence limit for the 86.5th percentile of this data is 13.6 (Fig. 6).

Table 8. Summary statistics

\begin{tabular}{lr}
\hline Sample size & 103 \\
Minimum value & 0.00 \\
25th percentile & 3.75 \\
Median value & 5.70 \\
Mean value & 7.77 \\
95\% UCL of mean & 9.89 \\
75th percentile & 7.65 \\
Maximum value & 125.90 \\
Standard deviation & 12.91 \\
\hline
\end{tabular}

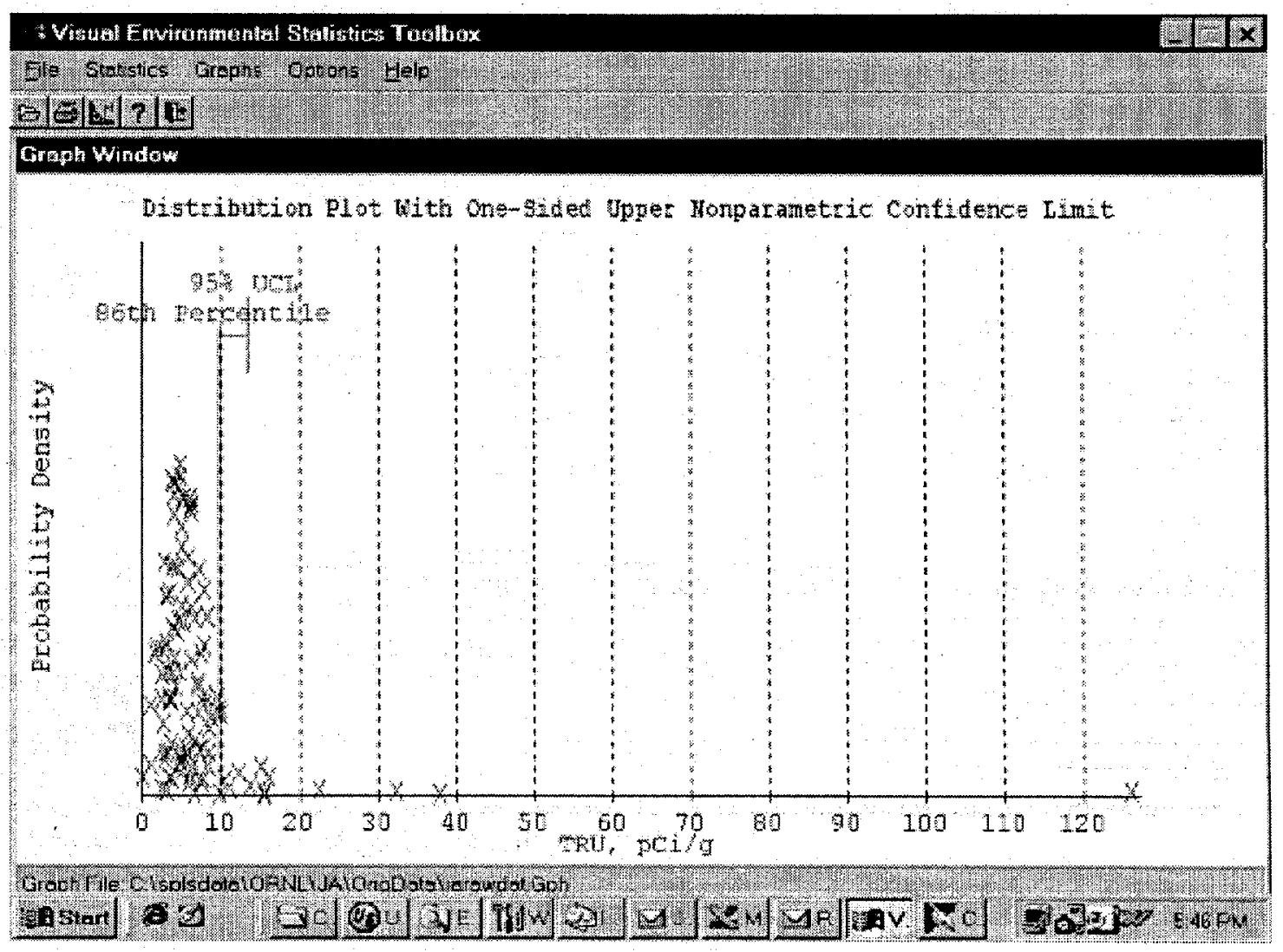

Fig. 6. Distribution of results. 
Tables 9 and 10 provide many different percentiles and nonparametric one-sided upper confidence limits. These "upper limits" are equivalent to nonparametric one-sided upper tolerance bounds, which are used in another statistical test for release surveys (Eger 1992). The one-sided upper $95 \%$ confidence limits for the mean $(7.77 \mathrm{pCi} / \mathrm{g})$ and the median $(5.7 \mathrm{pCi} / \mathrm{g})$ were both well below the $13.5-\mathrm{pCi} / \mathrm{g}$ concentration. The standard deviation of the concentrations is $12.91 \mathrm{pCi} / \mathrm{g}$.

Table 9. 90\% Upper confidence limits

\begin{tabular}{cccccc}
\hline Percentile & $\begin{array}{c}\text { Estimate } \\
\text { (pCi/g) }\end{array}$ & $\begin{array}{c}\text { Upper limit } \\
\text { (pCi/g) }\end{array}$ & Percentile & $\begin{array}{c}\text { Estimate } \\
\text { (pCi/g) }\end{array}$ & $\begin{array}{c}\text { Upper limit } \\
\text { (pCi/g) }\end{array}$ \\
\hline 50th & 5.70 & 6.00 & 91 th & 11.98 & 15.45 \\
75 th & 7.65 & 8.20 & 92 th & 13.46 & 15.68 \\
80th & 8.08 & 9.24 & 93 th & 14.90 & 17.14 \\
85th & 9.16 & 10.67 & 94 th & 15.36 & 22.20 \\
86th & 9.76 & 11.28 & 95 th & 15.49 & 29.67 \\
87th & 9.90 & 12.37 & 96 th & 15.96 & 34.88 \\
88th & 9.90 & 13.68 & 97 th & 22.02 & 51.78 \\
89th & 10.37 & 14.89 & 98 th & 31.90 & 106.60 \\
90th & 10.90 & 15.31 & 99 th & 37.69 & N/A \\
\hline
\end{tabular}

Table 10. 95\% Upper confidence limits

\begin{tabular}{cccccc}
\hline Percentile & $\begin{array}{c}\text { Estimate } \\
(\mathrm{pCi} / \mathrm{g})\end{array}$ & $\begin{array}{c}\text { Upper limit } \\
(\mathrm{pCi} / \mathrm{g})\end{array}$ & Percentile & $\begin{array}{c}\text { Estimate } \\
(\mathrm{pCi} / \mathrm{g})\end{array}$ & $\begin{array}{c}\text { Upper limit } \\
(\mathrm{pCi} / \mathrm{g})\end{array}$ \\
\hline 50th & 5.70 & 6.10 & 91 th & 11.98 & 15.80 \\
75 th & 7.65 & 8.35 & 92 th & 13.46 & 18.36 \\
80th & 8.08 & 9.90 & 93 th & 14.90 & 23.58 \\
85th & 9.16 & 11.79 & 94 th & 15.36 & 30.76 \\
86th & 9.76 & 12.97 & 95 th & 15.49 & 35.26 \\
87th & 9.90 & 14.20 & 96 th & 15.96 & 54.65 \\
88th & 9.90 & 15.16 & 97 th & 22.02 & 107.20 \\
89th & 10.37 & 15.40 & $98 \mathrm{th}$ & 31.90 & N/A \\
90th & 10.90 & 15.48 & 99th & 37.69 & N/A \\
\hline
\end{tabular}

The statistical approach here (Sect. 2.1 and ORNL 1998a) is a relatively stringent test compared to other statistical methods such as the sign test described in the MARSSIM (EPA 1997). According to the MARSSIM, the sign test should be used with an elevated measurement comparison (EMC) where each measurement is compared to the DCGL-EMC. The MARSSIM states "If a measurement exceeds this DCGL, then additional investigation is recommended, a least locally, to determine the actual extent of the elevated concentration."

Although this survey was not designed to use the sign test, the data here would demonstrate that the median $(50 \%)$ of the clean storage pile is below the $13.5-\mathrm{pCi} / \mathrm{g}$ DCGL. With the caveat that additional investigation of elevated concentrations was not performed, the data pass the sign test at $13.5 \mathrm{pCi} / \mathrm{g}$. 


\section{CONCLUSIONS AND RECOMMENDATIONS}

The purpose of this IV survey was to show with high confidence (95\%) that a large proportion $(97 \%)$ of the clean storage pile was less than the selected guideline of $13.5 \mathrm{pCi} / \mathrm{g}$. Although the results of the survey failed to achieve this goal, several projections can be applied to the radiological status of the clean pile using the same test, such as suggesting that $88 \%$ of the clean storage pile was below $13.5 \mathrm{pCi} / \mathrm{g}$. Furthermore, no hot particles were found within the top $1 \mathrm{~cm}$ of the survey units that were gamma scanned (10\% of the total area). Although it is nearly impossible to statistically prove that no hot particles exist in over 80,000 metric tons of material, the gamma scan data are good indicators that hot particles have been significantly reduced.

The SAP proposed to examine both QC soils sample data and soil sorter data collected by Thermo NUtech and to present a general distribution of activity from the many years of soils sorting. This evaluation was not completed because Thermo NUtech has not issued its final report as the remedial action contractor and has not submitted six of the last sets of QC data. Previous examination of Thermo NUtech's QC samples analyzed for total TRU activity data by the IV contractor (for one quarter only) showed all results to be below $13.5 \mathrm{pCi} / \mathrm{g}$ (ORNL 1998a). Furthermore, the IV examination of the soil sorter hardware and software indicated that the decontamination was effective and significantly reduced plutonium contamination in the soil processed at the site.

Based on the results of this survey, we have the following recommendations to support any further decision-making by the DTRA: (1) examine Thermo NUtech's final report and the entirety of the soil sorting data and QC results, (2) restate the soil screening limit in terms of an acceptable confidence level, (3) reevaluate the appropriateness of the selected soil screening limit, (4) conduct another IV survey after any planned recontouring of the clean storage pile, (5) conduct a data quality objectives process before performing further verification efforts, and (6) acquire regulatory

approval of the release of the clean storage pile. Historical information and other recommendations are provided in ORNL 1988a. 


\section{REFERENCES}

ANSI 1978. American National Standard Institute, Radiation Protection Instrumentation Test and Calibration, ANSI N323-1978.

DNA 1991. Letter to J. Eddy, Defense Special Weapons Agency Headquarters from E. T. Bramlitt, FCDSWA (formerly FCDNA), JA Cleanup Technical Manager, March 1, 1991.

DNA 1992. Plutonium Mining Fact Sheet. Defense Special Weapons Agency, Field Command Defense Special Weapons Agency, Kirtland Air Force Base, New Mexico.

Eger, K. J. 1992. "The Use of One-Sided Tolerance Tests for Surveys during Decontamination and Decommissioning" in Waste Management and Environmental Restoration, Proceedings of the 8th Annual DOE Model Conference, Oak Ridge, Tennessee, October 18-22, 1992.

FCDSWA 1997. Memorandum for M. J. Wilson-Nichols, Lockheed Martin Energy Research Corp., Oak Ridge National Laboratory, from Captain D. Rynders. Subject: Proposal of Final Survey Plan for Johnston Atoll (Clean Coral Storage Pile and Internal Areas) July 3, 1997.

ORNL 1998a. Final Independent Verification of Plutonium Decontamination on Johnston Atoll (1992 - 1996) Interim Report. ORNL/TM-13397, Lockheed Martin Energy Research Corp., Oak Ridge National Laboratory.

ORNL 1998b. Letter to Captain D. Rynders from M. J. Wilson-Nichols, Lockheed Martin Energy Research Corp., Oak Ridge National Laboratory, "Independent Verification Proposal for the Johnston Atoll Clean Storage Pile," June 5, 1998.

ORNL 1999. Independent Verification Sample and Analysis Plan for the Johnston Atoll Clean Coral Storage Pile. Lockheed Martin Energy Research Corp., Oak Ridge National Laboratory, January 8, 1999.

Thermo NUtech 1997. Radiological Characterization of the Johnston Atoll Plutonium Contaminated Launch Facility Using Global Positioning Satellites. Thermo NUtech, Knoxville, Tennessee.

U.S. EPA 1997. Multi-Agency Radiation Survey and Site Investigation Manual (MARSSIM). EPA 402-R-97-016 (NUREG-1575), U.S. Environmental Protection Agency, December.

Wolf, S. F., J. K. Bates, N. R. Brown, E. C. Buck, N. D. Dietz, J. A. Fortner, and M. Gong 1995. Characterization Studies of Actinide Contamination on Johnston Atoll. Argonne National Laboratory, Argonne, Illinois. 
Appendix A

PHOTOGRAPH LOG 
A-2 

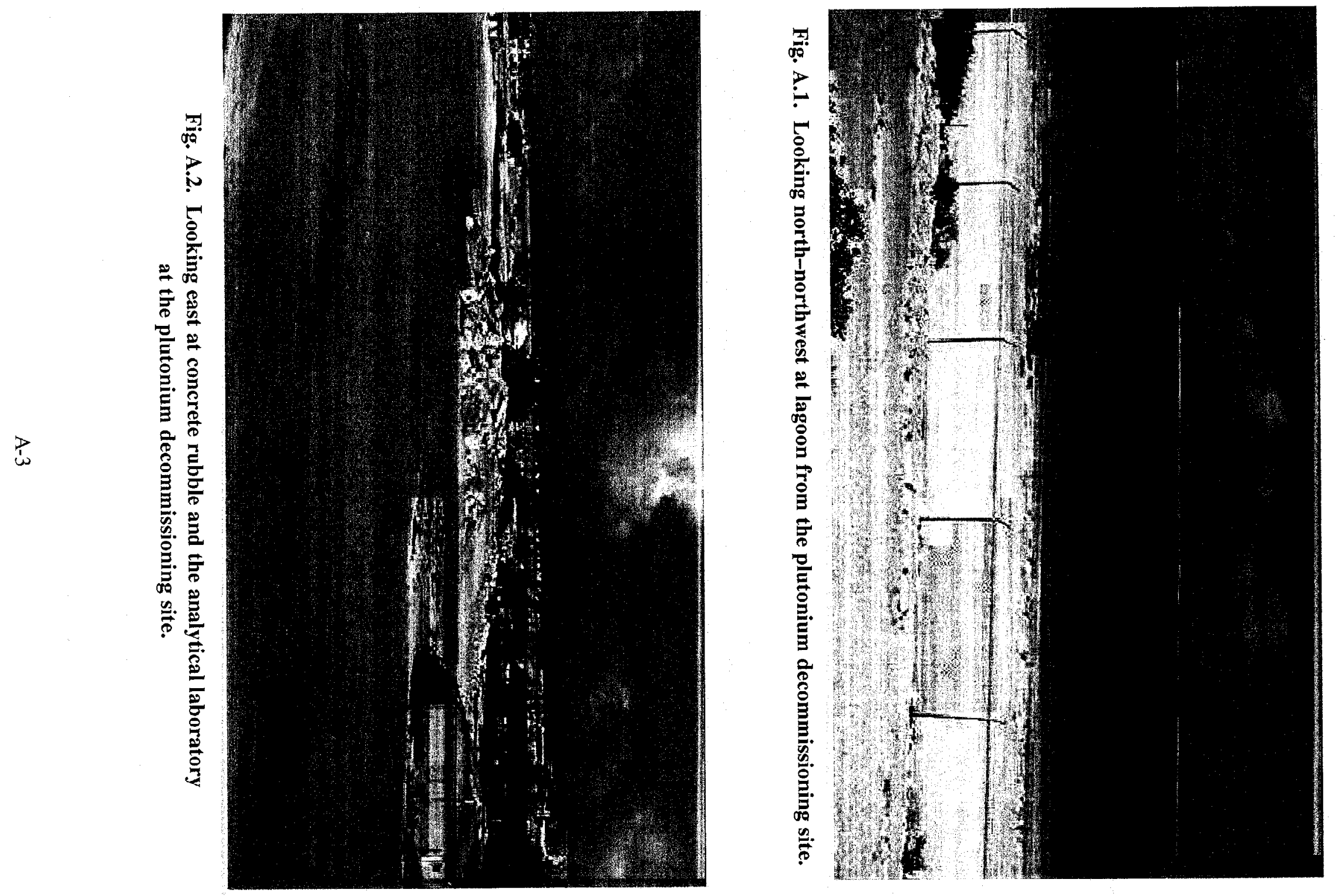
-

$=$ 


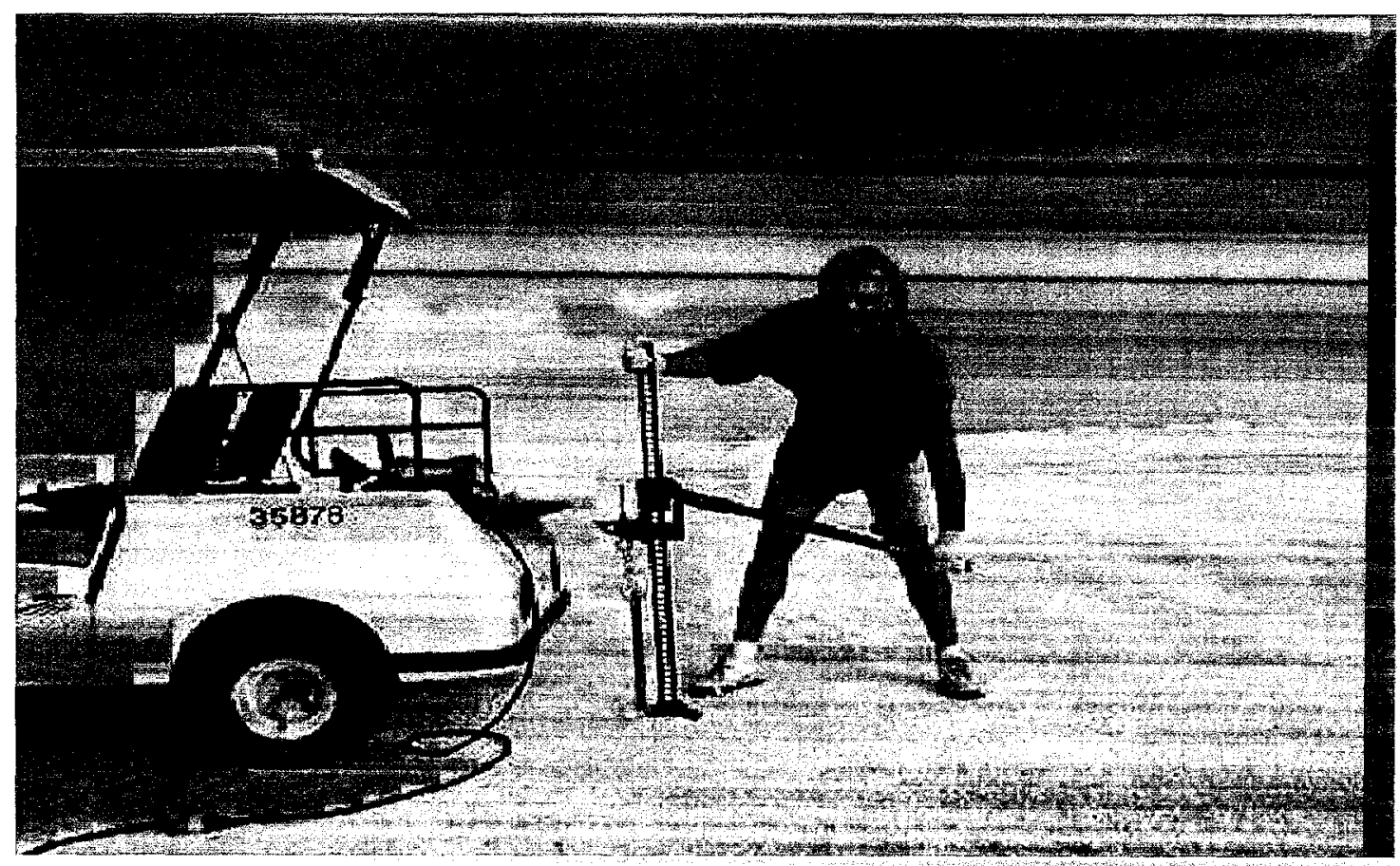

Fig. A.3. Collecting coral samples at 1- to 4-ft depths from the clean pile.

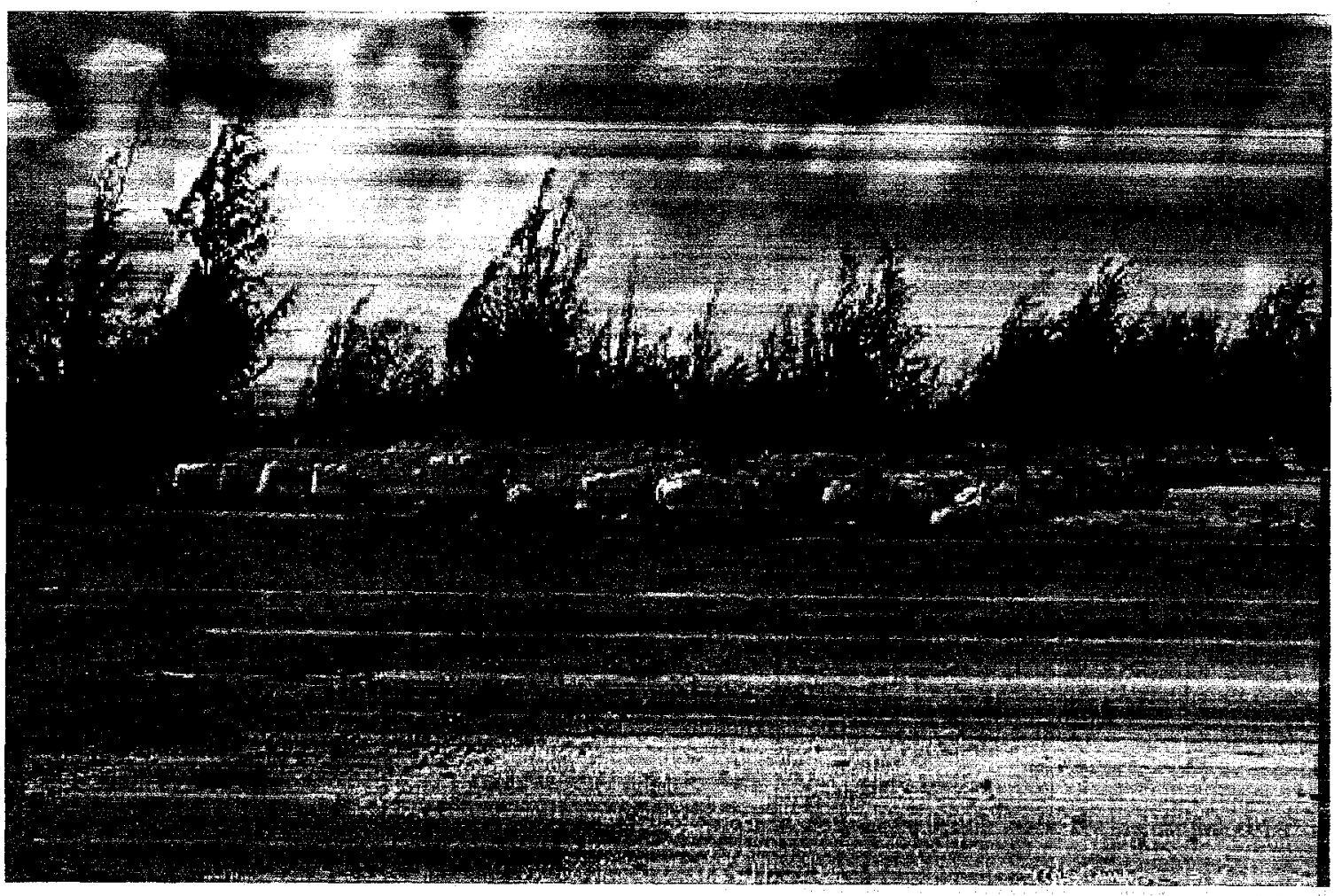

Fig. A.4. Waste storage at the plutonium decontamination project. 



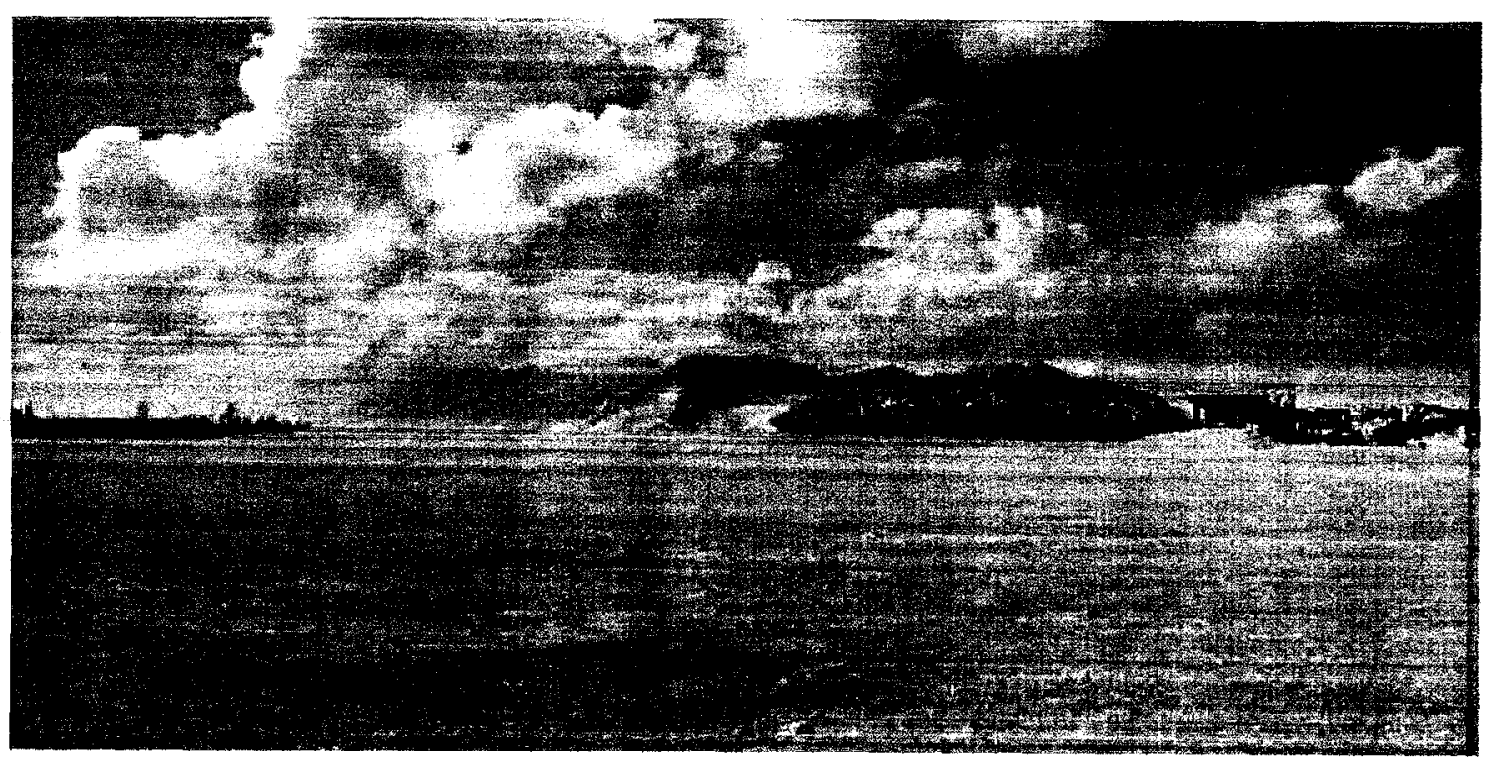

Fig. A.5. Looking north at "Mount Pluto."

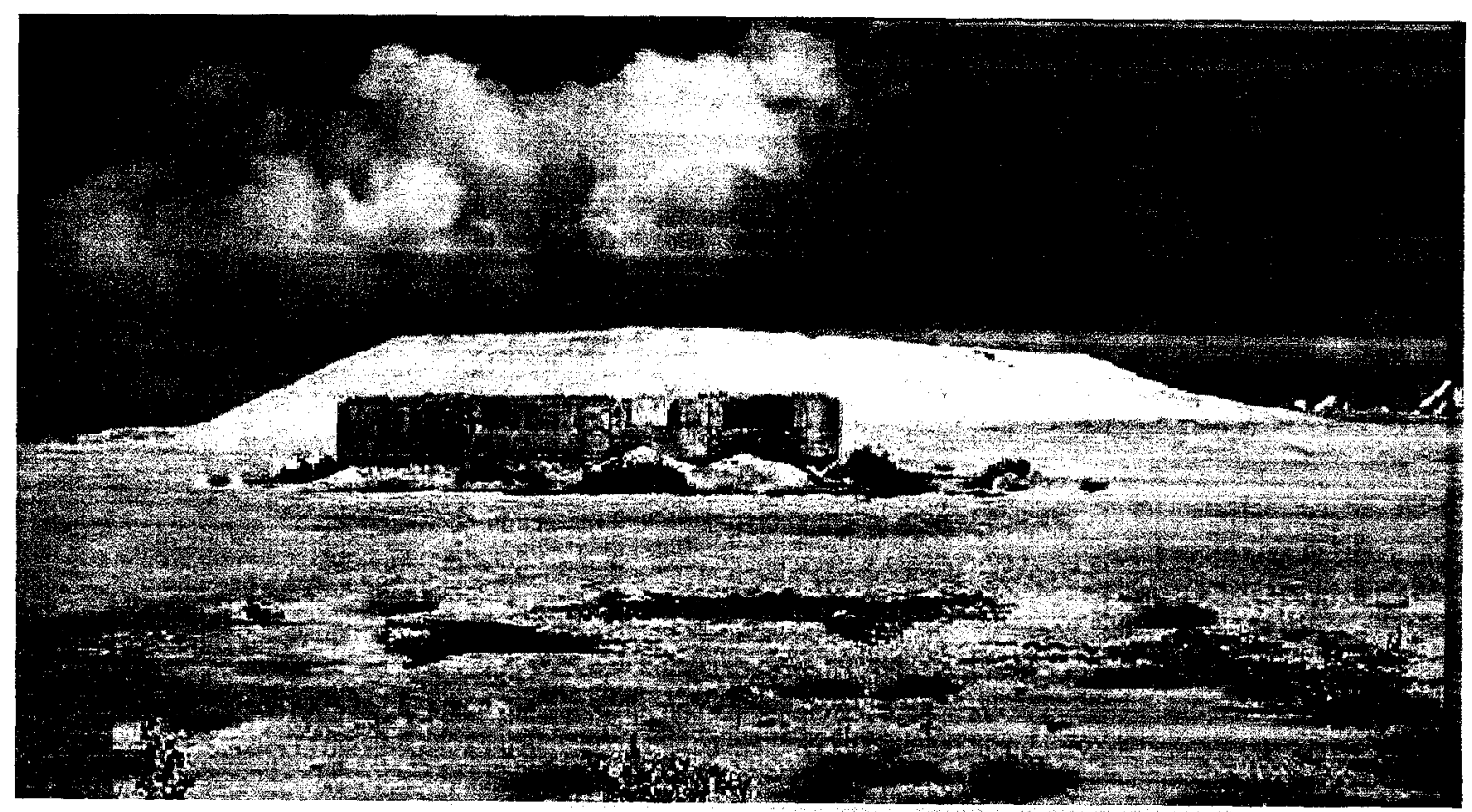

Fig. A. 6. Looking north at the clean storage pile. 
$$
\text { . }
$$ 


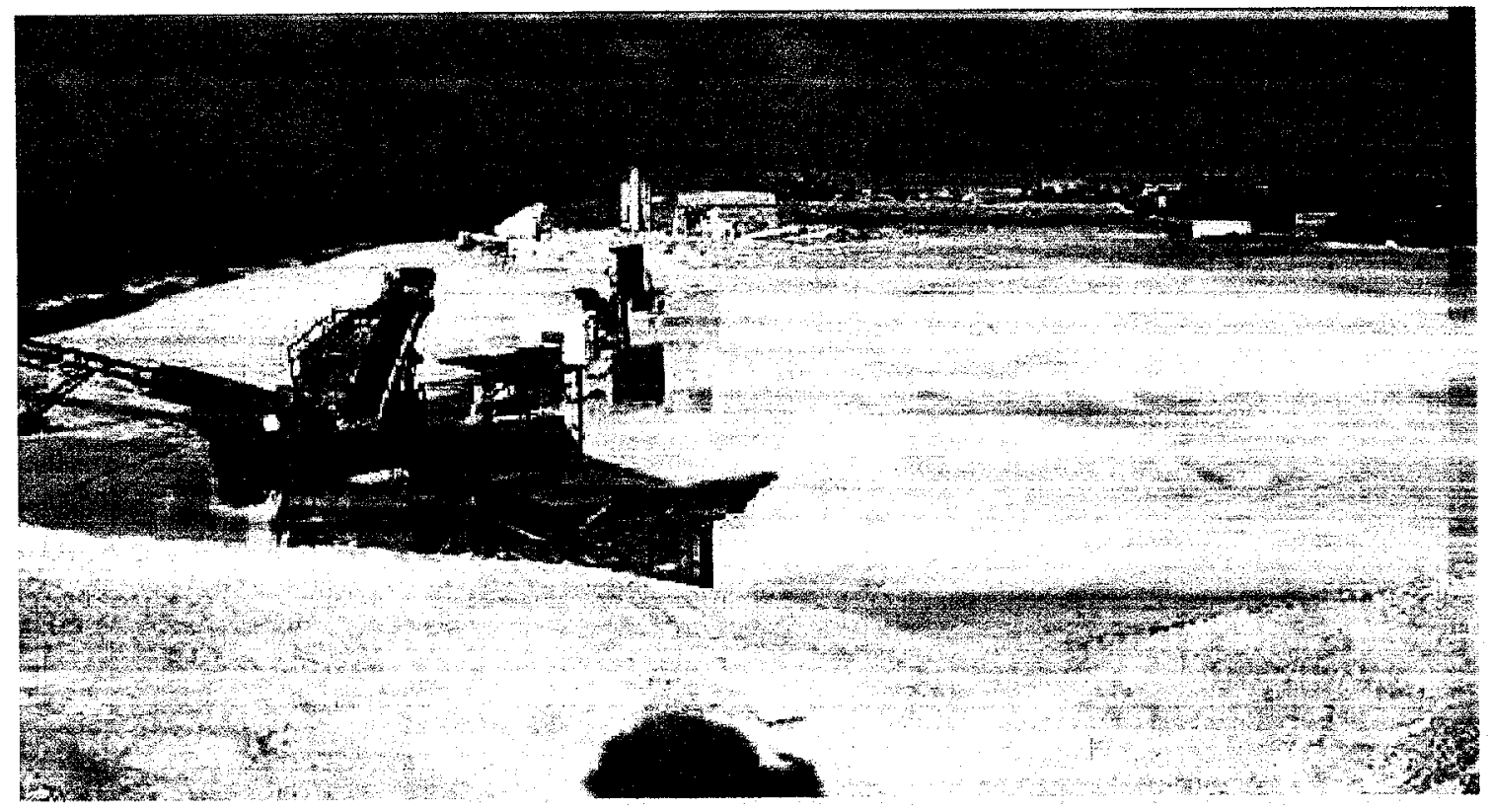

Fig. A.7. Looking northeast at the clean storage pile.

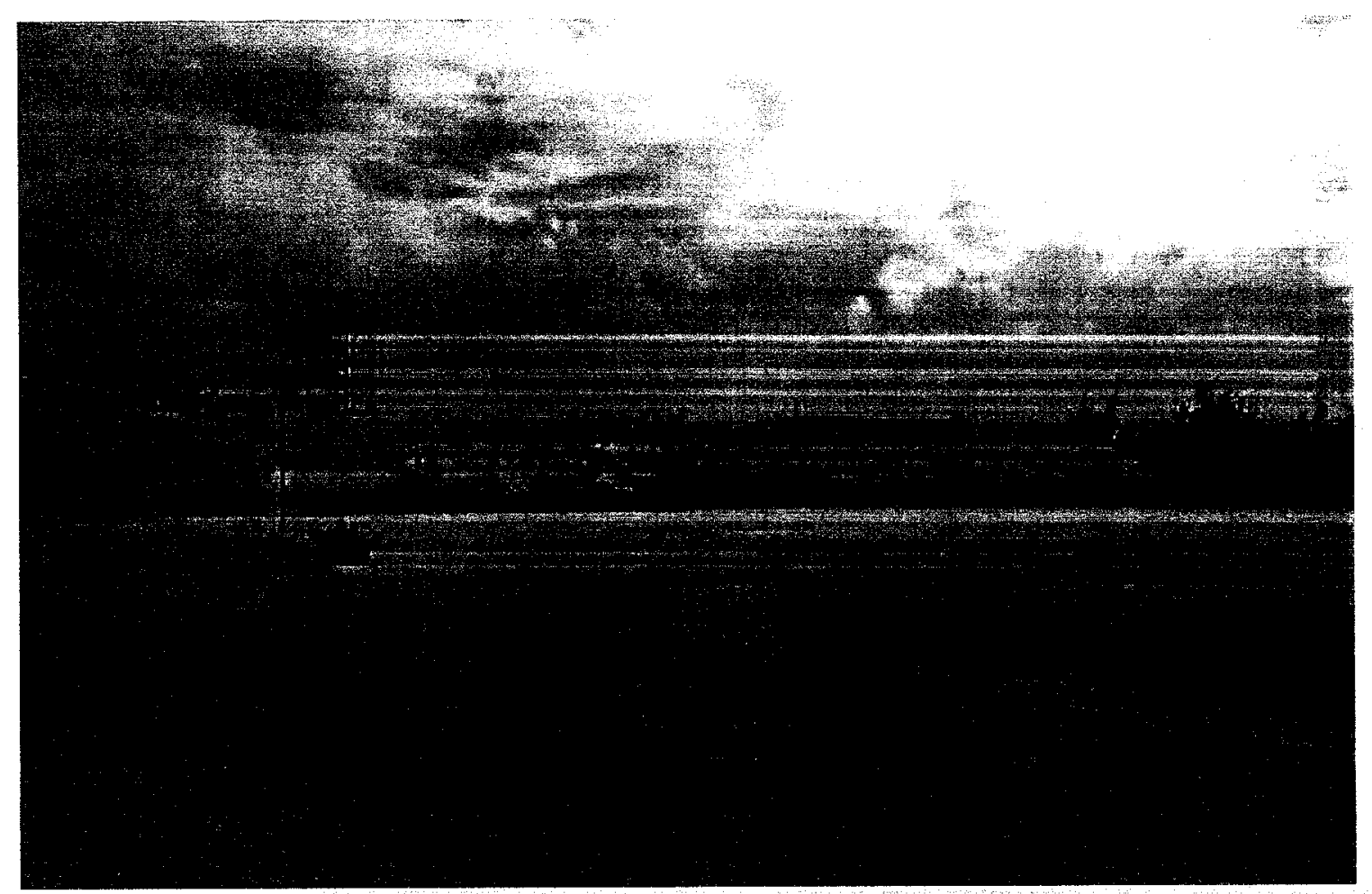

Fig. A.8. Looking northeast at the clean storage pile. 



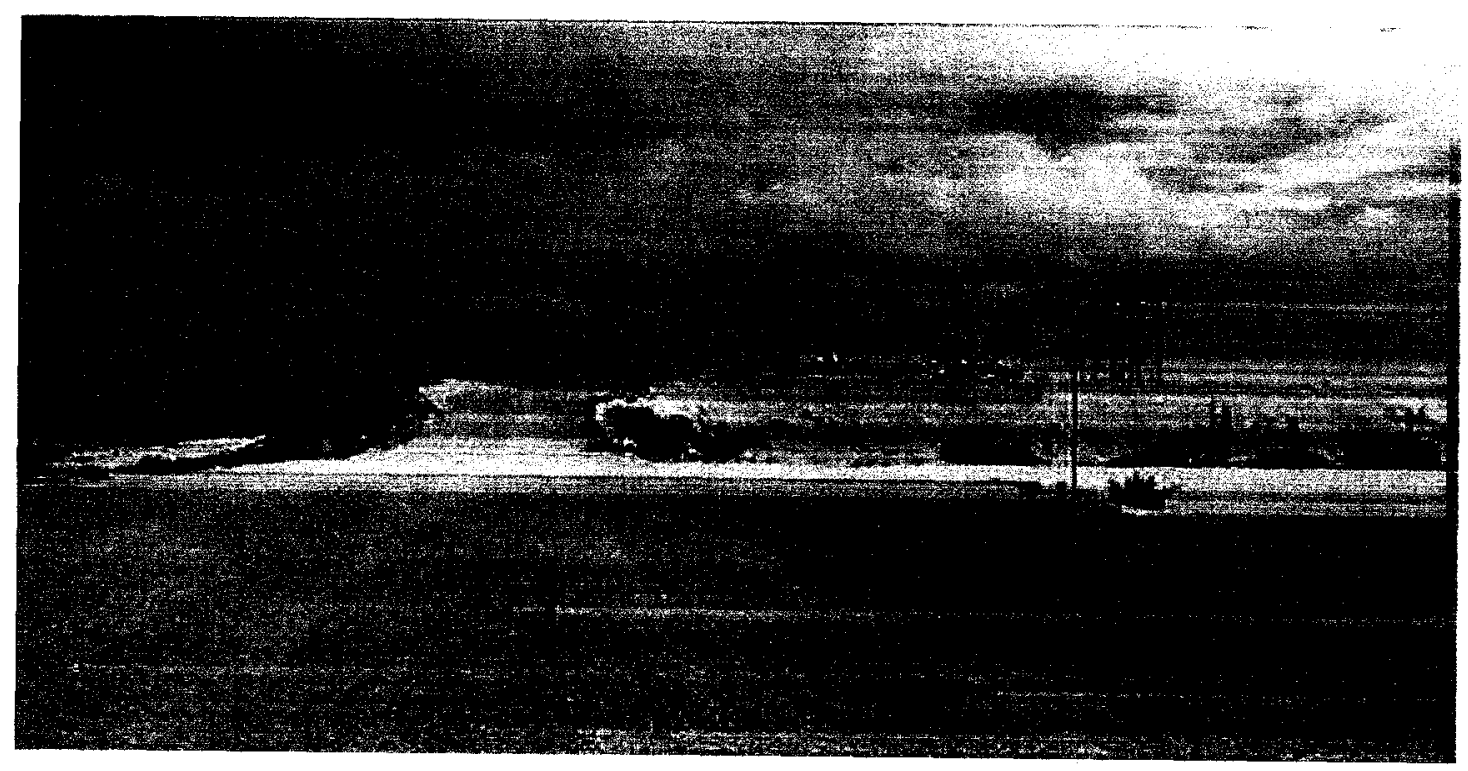

Fig. A.9. Looking northeast at the access to the clean storage pile.

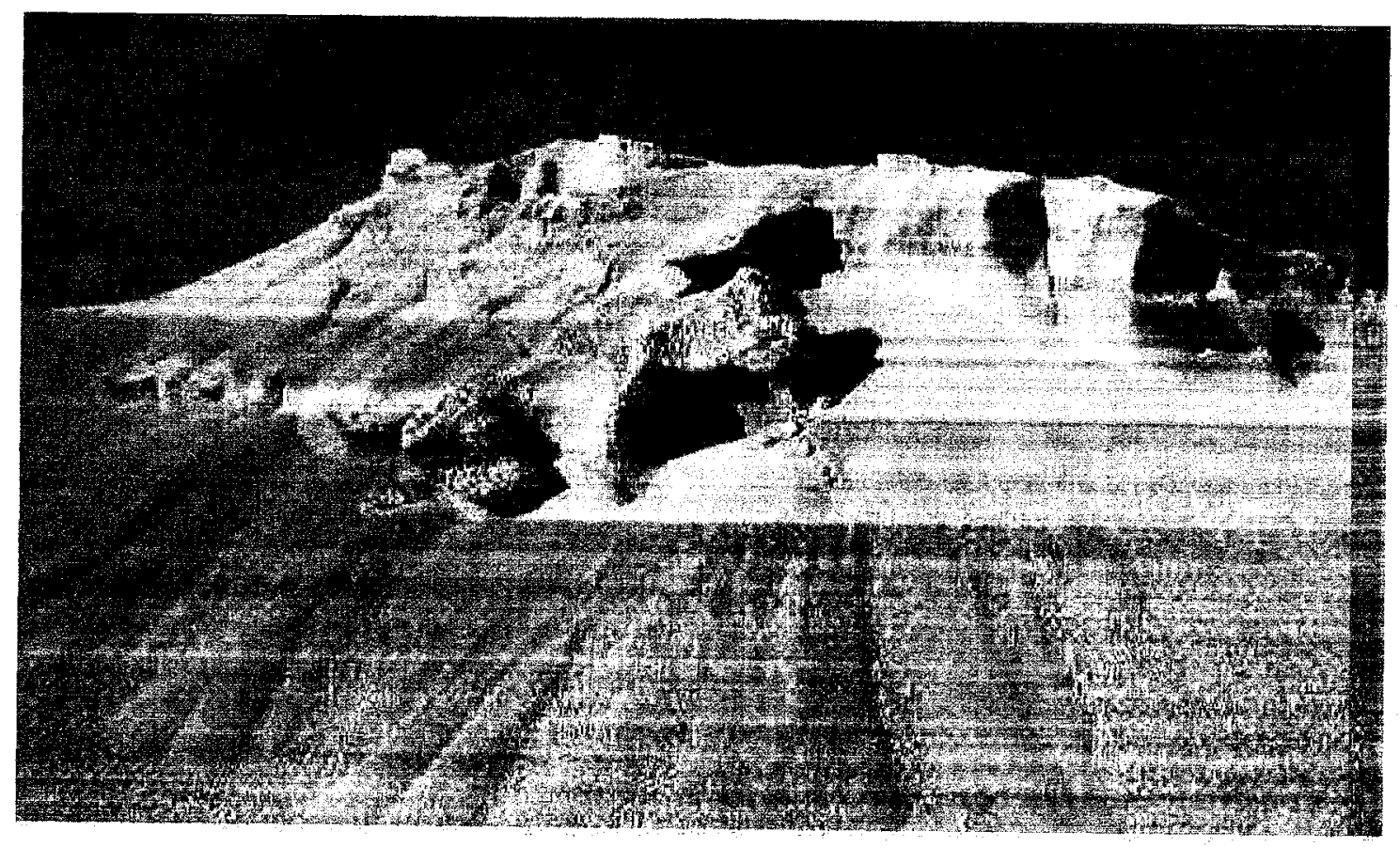

Fig. A.10. Effects of erosion on "Mount Pluto." 


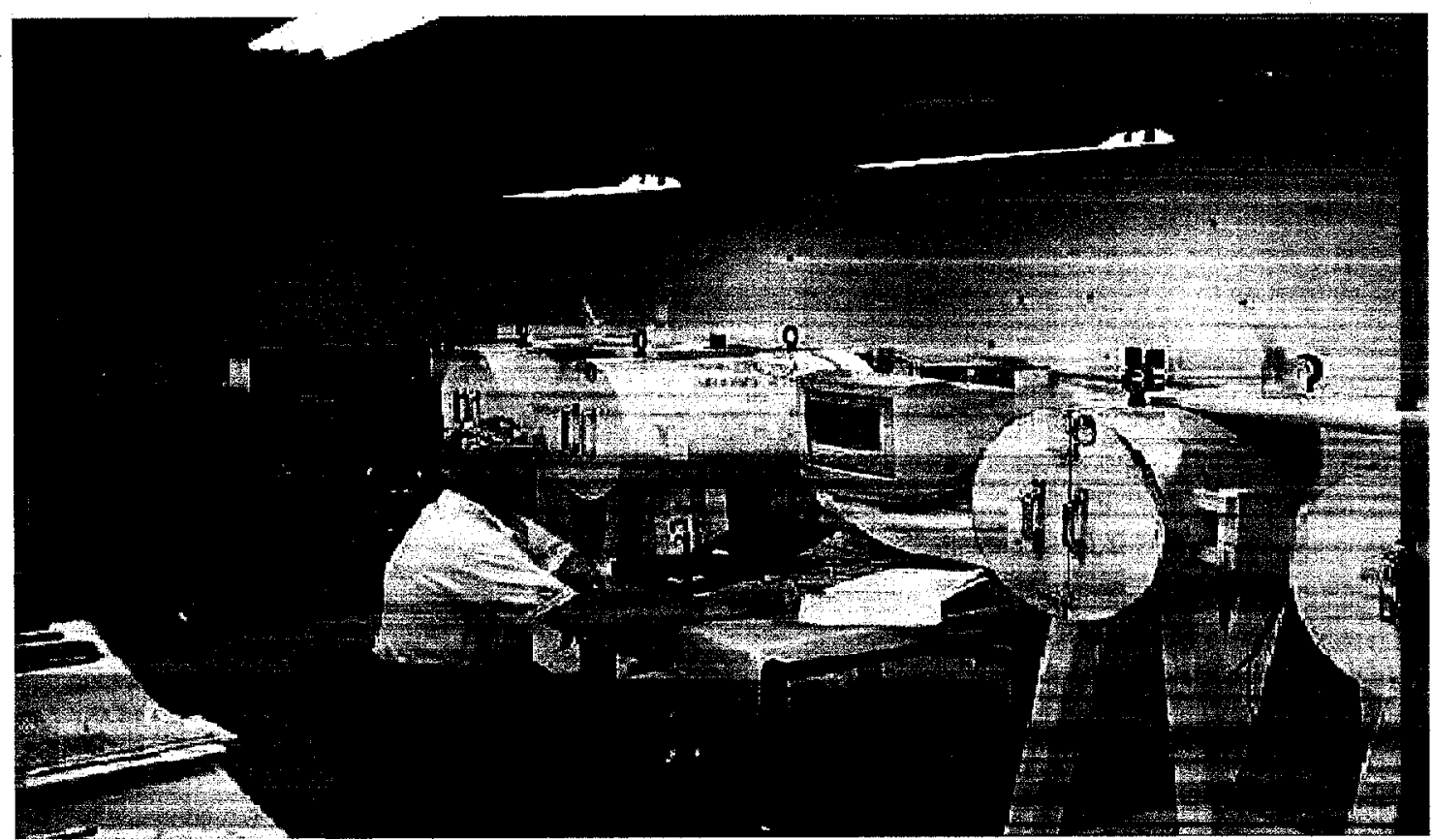

Fig. A.11. Radioanalytical counting laboratory at JA.

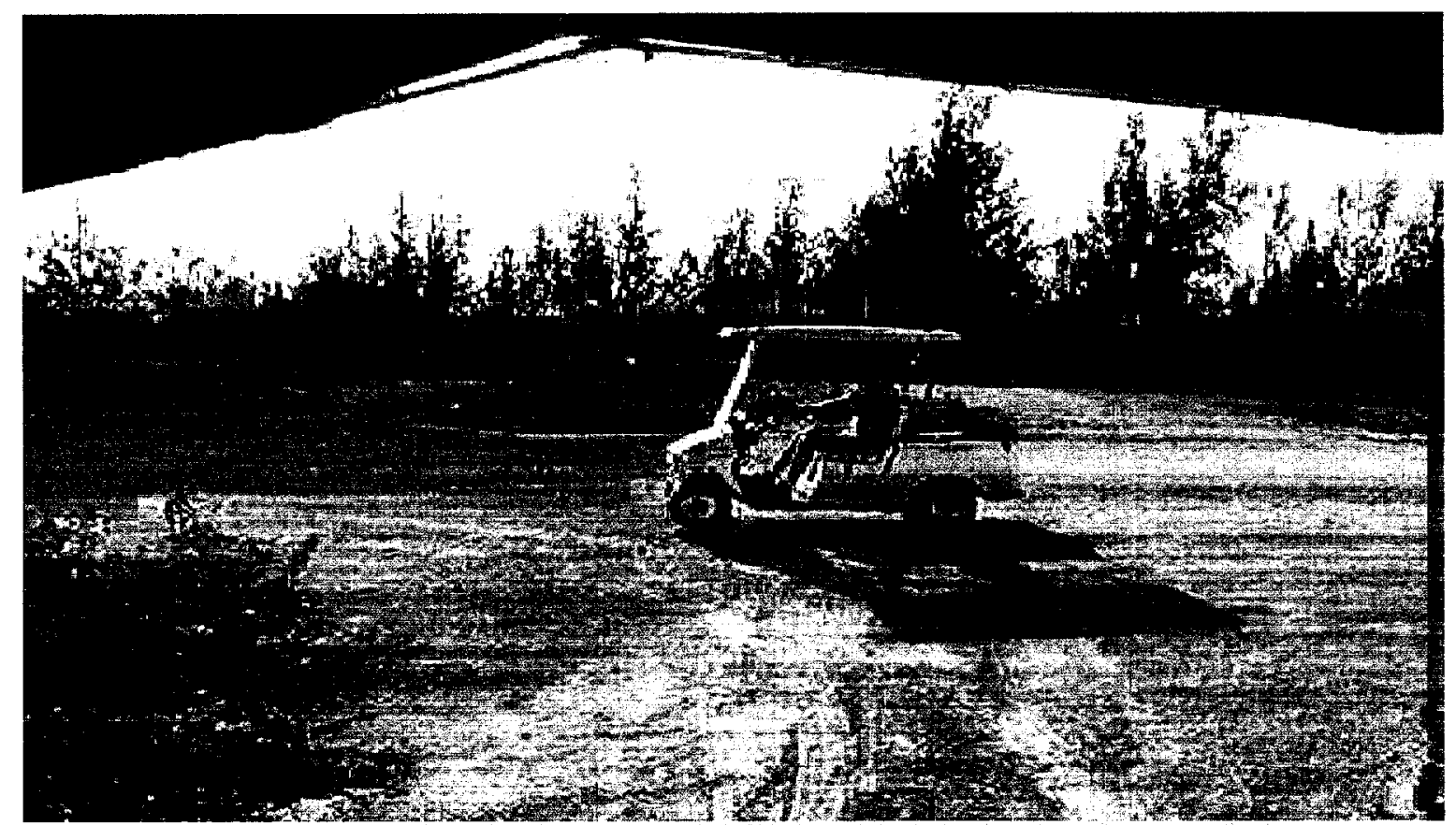

Fig. A.12. Using motorized vehicle to collect samples from the clean pile. 


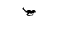




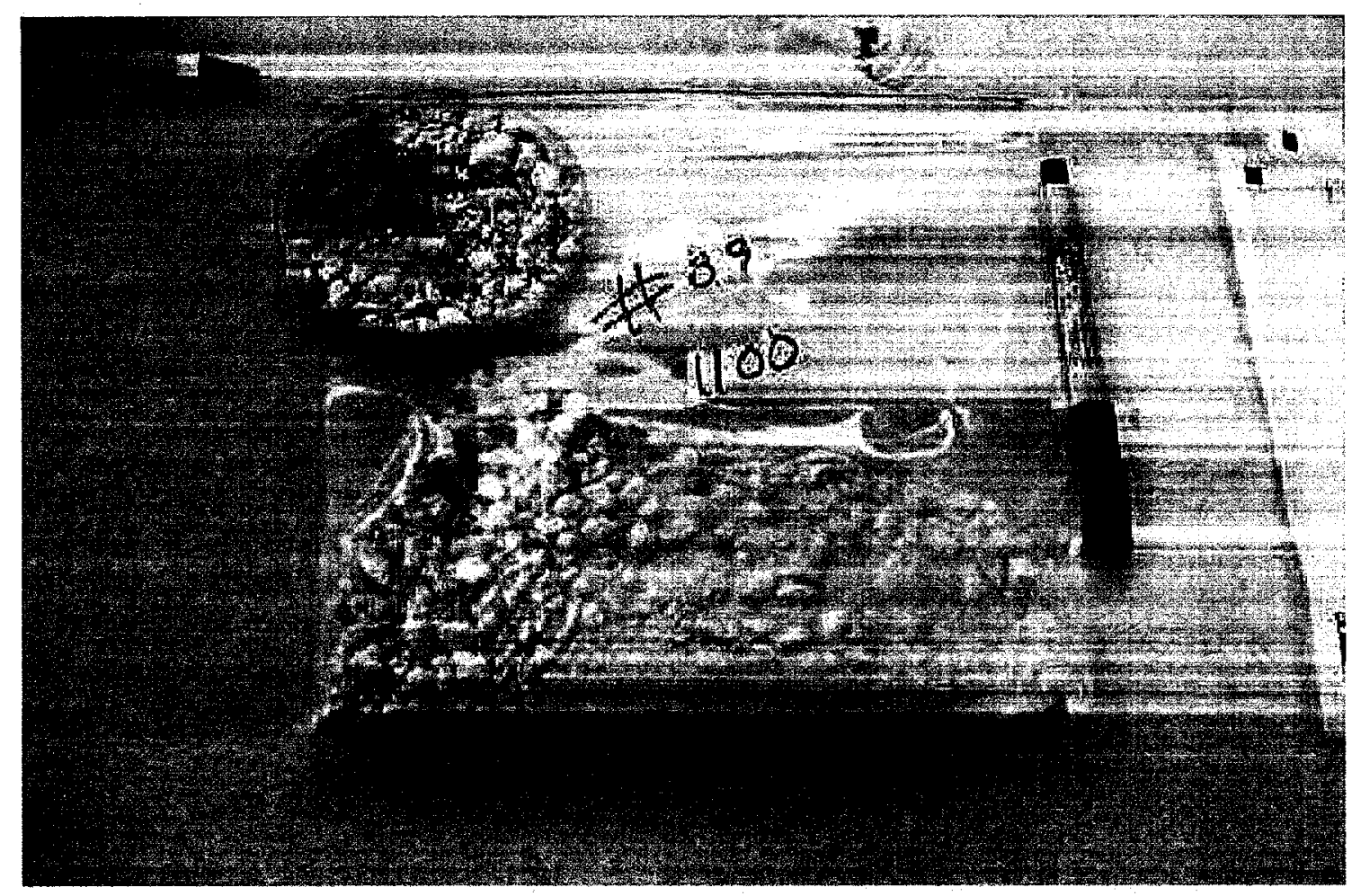

Fig. A.13. IV sample (unsieved) from the clean storage pile.

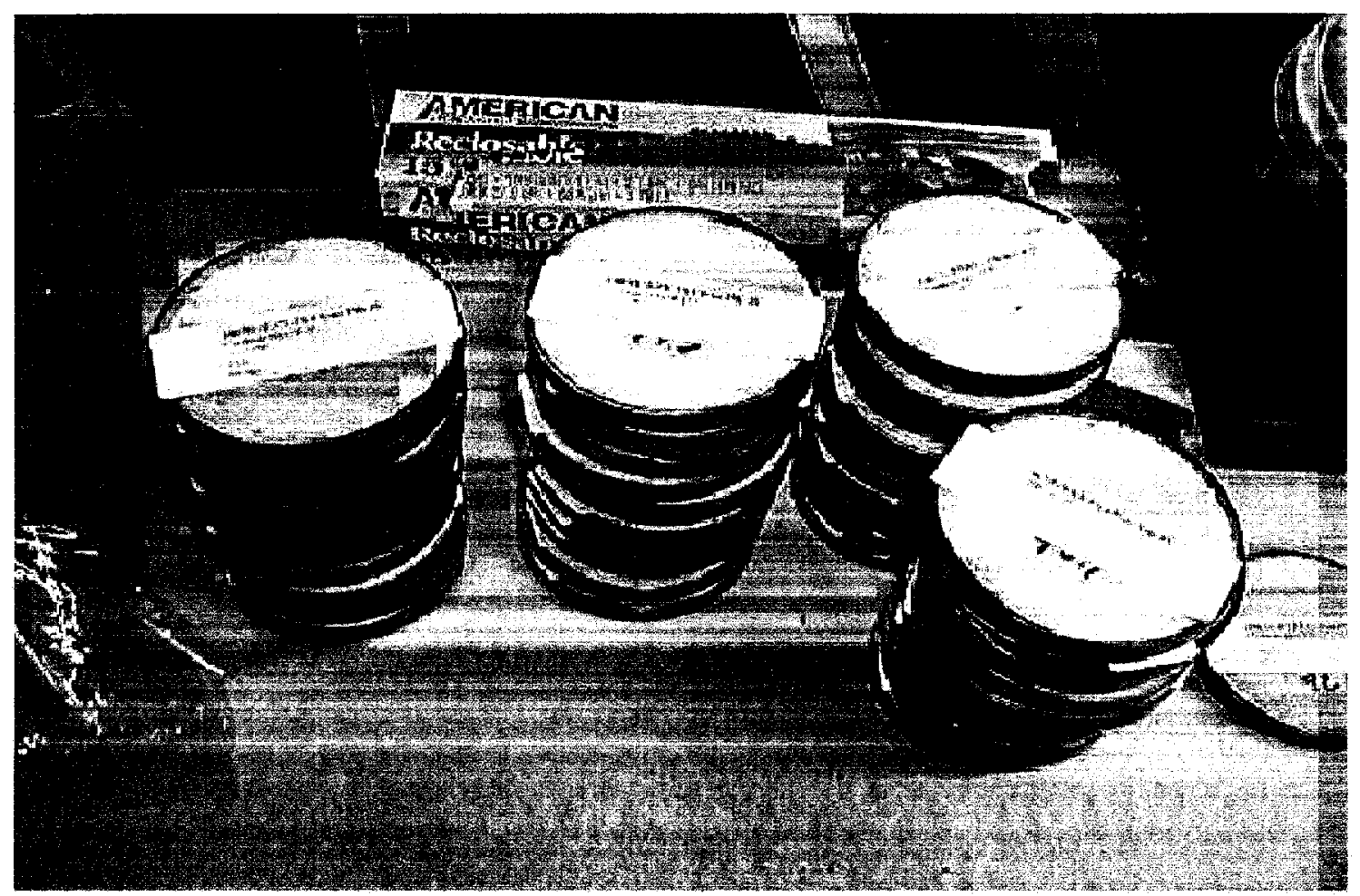

Fig. A.14. Packaged samples from the clean storage pile. 


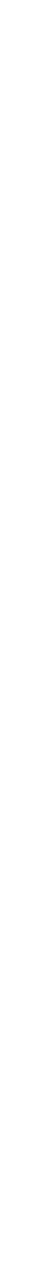




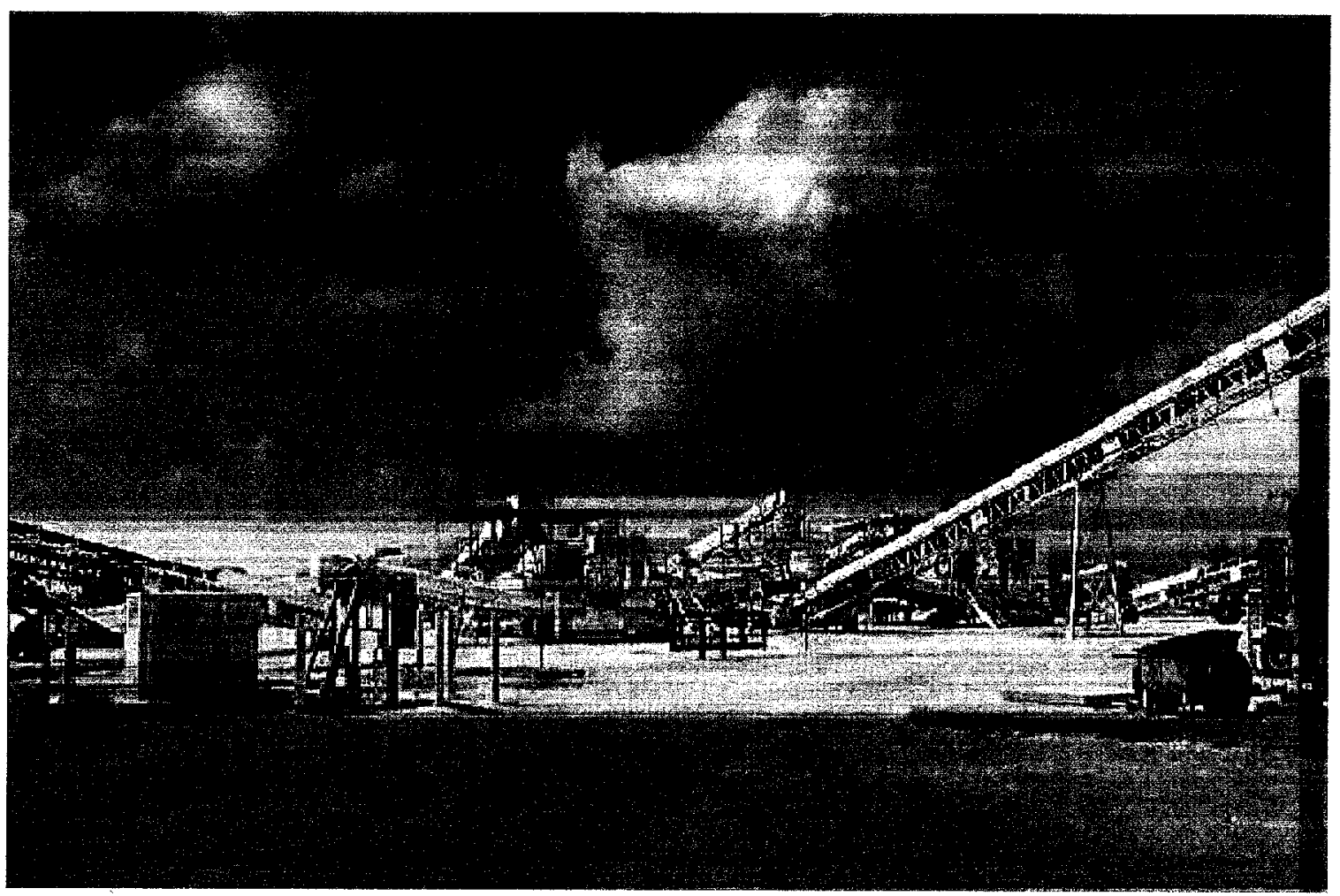

Fig. A.15. Remains of the soil sorting system at JA. 

Appendix B

RESULTS FROM ON-SITE RADIOANALYTICAL LABORATORY 
B-2 
Table B.1. Results of on-site analysis ${ }^{a}$

\begin{tabular}{|c|c|c|c|c|c|c|c|c|c|c|c|c|c|c|c|c|c|c|c|}
\hline $\begin{array}{l}\text { Location } \\
\text { No. }\end{array}$ & $X(m)$ & $Y(m)$ & $Z(\mathrm{ft})$ & $\begin{array}{c}\text { Date } \\
\text { collected }\end{array}$ & Time & ANS No. & $\begin{array}{l}\text { Date } \\
\text { counted }\end{array}$ & Time & $\begin{array}{l}\text { Weight } \\
\text { (g) }\end{array}$ & $\begin{array}{l}\text { Live } \\
\text { time (s) }\end{array}$ & $\begin{array}{l}\text { Ambient } \\
\text { back- } \\
\text { ground } \\
\text { counts }\end{array}$ & $\begin{array}{l}\text { Gross } \\
\text { counts }\end{array}$ & $\begin{array}{l}\text { Net } \\
\text { counts }\end{array}$ & Sigma & $\begin{array}{l}\text { Gross } \\
\text { activity } \\
\text { (pCi) }\end{array}$ & Sigma & $\begin{array}{l}\text { Specific } \\
\text { activity } \\
\text { (pCi/g) }\end{array}$ & Sigma & $\begin{array}{c}\mathrm{MDC} \\
(\mathrm{pCi} / \mathrm{g})\end{array}$ \\
\hline 1 & 0.04 & 108.35 & 0.7 & $1 / 20 / 1999$ & 1436 & $\mathrm{C} 000001$ & $1 / 21 / 1999$ & 11:16 & 75 & 900 & 927 & 1102 & 176 & 37 & 377.4 & 78.9 & 5 & 1 & 0.1 \\
\hline 2 & 0.41 & 84.77 & 3.1 & $1 / 20 / 1999$ & 1448 & $\mathrm{C} 000001$ & $1 / 22 / 1999$ & $8: 34$ & 84 & 900 & 917 & 1080 & 163 & 36 & 350.5 & 78.1 & 4.2 & 0.9 & 0.1 \\
\hline 3 & -1.08 & 45.46 & 0.1 & $1 / 20 / 1999$ & 1628 & $\mathrm{C} 000014$ & $1 / 21 / 1999$ & $17: 06$ & 92 & 900 & 927 & 1231 & 305 & 38 & 654.8 & 83.2 & 7.1 & 0.9 & 0.1 \\
\hline 4 & 1.91 & 21.88 & 3.2 & $1 / 21 / 1999$ & 807 & $\mathrm{C} 000028$ & $1 / 23 / 1999$ & $9: 00$ & 95 & 900 & 931 & 1083 & 152 & 36 & 326.9 & 78.3 & 3.4 & 0.8 & 0.1 \\
\hline 5 & -10.04 & 92.63 & 0 & $1 / 20 / 1999$ & 1510 & $\mathrm{C} 000003$ & $1 / 22 / 1999$ & $9: 14$ & $86^{\circ}$ & 900 & 917 & 1168 & 251 & 37 & 539.8 & 81.1 & 6.3 & 0.9 & 0.1 \\
\hline 6 & 10.87 & 116.21 & 3.4 & $1 / 20 / 1999$ & 1517 & $\mathrm{C} 000012$ & $1 / 21 / 1999$ & $16: 15$ & 83 & 900 & 927 & 1096 & 170 & 36 & 364.5 & 78.7 & 4.4 & 1 & 0.1 \\
\hline 7 & 100.48 & 15.98 & 0.7 & $1 / 21 / 1999$ & 1220 & $\mathrm{C} 000001$ & 1/24/1999 & $10: 29$ & 92 & 900 & 947 & 1053 & 106 & 36 & 227.4 & 77.4 & 2.5 & 0.8 & 0.1 \\
\hline 8 & 104.59 & 42.19 & 2.1 & $1 / 21 / 1999$ & 1230 & $\mathrm{C} 000031$ & $1 / 23 / 1999$ & $9: 54$ & 102 & 900 & 931 & 1107 & 176 & 37 & 378.5 & 79.1 & 3.7 & 0.8 & 0.1 \\
\hline 9 & 104.96 & 0.26 & 3.2 & $1 / 21 / 1999$ & 1235 & $\mathrm{C} 000052$ & $1 / 23 / 1999$ & $17: 31$ & 87 & 900 & 957 & 1173 & 216 & 38 & 464 & 81.3 & 5.3 & 0.9 & 0.1 \\
\hline 10 & 109.44 & 38.69 & 1.3 & $1 / 21 / 1999$ & 1240 & $\mathrm{C} 000047$ & $1 / 23 / 1999$ & $15: 53$ & 95 & 900 & 957 & 1643 & 686 & 43 & 1474.7 & 97.5 & 15.5 & 1 & 0.1 \\
\hline 11 & -11.54 & 14.02 & 3.8 & $1 / 20 / 1999$ & 1611 & $\mathrm{C} 000015$ & 1/24/1999 & $15: 16$ & 85 & 900 & 947 & 1188 & 241 & 38 & 517.7 & 81.8 & 6.1 & 1 & 0.1 \\
\hline 12 & -11.91 & 40.22 & 1.1 & $1 / 20 / 1999$ & 1602 & $\mathrm{C} 000015$ & $1 / 21 / 1999$ & $17: 29$ & 87 & 900 & 927 & 1245 & 319 & 38 & 684.9 & 83.7 & 7.9 & 1 & 0.1 \\
\hline 13 & 11.99 & 37.6 & 1.2 & $1 / 21 / 1999$ & 901 & $\mathrm{C} 000012$ & $1 / 22 / 1999$ & $13: 08$ & 100 & 900 & 917 & 1184 & 267 & 38 & 574.2 & 81.6 & 5.7 & 0.8 & 0.1 \\
\hline 14 & 12.36 & 131.93 & 2.2 & $1 / 20 / 1999$ & 1526 & $\mathrm{C} 000010$ & $1 / 21 / 1999$ & $15: 35$ & 84 & 900 & 927 & 1333 & 407 & 40 & 874.2 & 86.7 & 10.5 & 1 & 0.1 \\
\hline 15 & -13.03 & -1.71 & 0.9 & $1 / 21 / 1999$ & 1248 & $\mathrm{C} 000032$ & 1/23/1999 & $10: 12$ & 97 & 900 & 931 & 1062 & 131 & 36 & 281.7 & 77.6 & 2.9 & 0.8 & 0.1 \\
\hline 16 & 13.85 & 91.75 & 2.9 & $1 / 20 / 1999$ & 1536 & $\mathrm{C} 000004$ & $1 / 21 / 1999$ & $13: 38$ & 102 & 900 & 927 & 1155 & 229 & 37 & 491.4 & 80.6 & 4.8 & 0.8 & 0.1 \\
\hline 17 & 14.97 & 63.8 & 2 & $1 / 21 / 1999$ & 812 & $\mathrm{C} 000044$ & 1/23/1999 & $14: 56$ & 94 & 900 & 957 & 1229 & 272 & 38 & 584.4 & 83.2 & 6.2 & 0.9 & 0.1 \\
\hline 18 & 15.35 & 6.16 & 3.7 & $1 / 21 / 1999$ & 845 & $\mathrm{C} 000046$ & 1/23/1999 & $15: 33$ & 95 & 900 & 957 & 1035 & 78 & 36 & 167.2 & 76.8 & 1.8 & 0.8 & 0.1 \\
\hline 19 & 16.84 & 41.53 & 0.4 & $1 / 21 / 1999$ & 1256 & $C 000039$ & $1 / 23 / 1999$ & $13: 26$ & 88 & 900 & 957 & 1148 & 191 & 37 & 410.2 & 80.5 & 4.7 & 0.9 & 0.1 \\
\hline 20 & 17.96 & 99.18 & 3.5 & $1 / 20 / 1999$ & 1545 & C000009 & $1 / 21 / 1999$ & $15: 16$ & 87 & 900 & 927 & 1328 & 402 & 39 & 863.4 & 86.5 & 9.9 & 1 & 0.1 \\
\hline 21 & 18.33 & 25.81 & 2.5 & $1 / 20 / 1999$ & 1622 & $\mathrm{C} 000011$ & $1 / 21 / 1999$ & $15: 56$ & 78 & 900 & 927 & 1104 & 178 & 37 & 381.7 & 78.9 & 4.9 & 1 & 0.1 \\
\hline 22 & 19.83 & 127.13 & 2.7 & $1 / 20 / 1999$ & 1557 & C000008 & $1 / 21 / 1999$ & $14: 57$ & 81 & 900 & 927 & 2348 & 1422 & 51 & 3056.9 & 124.1 & 37.8 & 1.5 & 0.1 \\
\hline 23 & -2.57 & 29.74 & 4 & $1 / 20 / 1999$ & 1615 & $\mathrm{C} 000007$ & $1 / 21 / 1999$ & $14: 36$ & 85 & 900 & 927 & 1466 & 540 & 41 & 1160.2 & 91.4 & 13.7 & 1.1 & 0.1 \\
\hline 24 & -2.95 & 87.39 & 2.2 & $1 / 21 / 1999$ & 852 & $\mathrm{C} 000030$ & $1 / 23 / 1999$ & $9: 38$ & 86 & 900 & 931 & 1053 & 122 & 36 & 262.4 & 77.3 & 3.1 & 0.9 & 0.1 \\
\hline 25 & 20.58 & 79.96 & 3.6 & $1 / 20 / 1999$ & 1634 & $\mathrm{C} 000003$ & $1 / 21 / 1999$ & $13: 20$ & 74 & 900 & 927 & 1346 & 420 & 40 & 902.1 & 87.2 & 12.2 & 1.2 & 0.1 \\
\hline 26 & 20.95 & -10.88 & 0.2 & $1 / 21 / 1999$ & 1300 & $\mathrm{C} 000015$ & $1 / 22 / 1999$ & $14: 17$ & 89 & 900 & 917 & 1243 & 326 & 38 & 701.1 & 83.6 & 7.9 & 0.9 & 0.1 \\
\hline 27 & 21.32 & 135.86 & 0.5 & $1 / 21 / 1999$ & 1305 & $\mathrm{C} 000045$ & $1 / 23 / 1999$ & $15: 13$ & 91 & 900 & 957 & 1279 & 322 & 39 & 691.9 & 84.9 & 7.6 & 0.9 & 0.1 \\
\hline 28 & 22.82 & 10.09 & 0.1 & $1 / 21 / 1999$ & 1310 & $\mathrm{C} 000005$ & $1 / 22 / 1999$ & $9: 57$ & 88 & 900.01 & 917 & 1572 & 655 & 42 & 1408.5 & 95.2 & 16 & 1.1 & 0.1 \\
\hline 29 & 23.94 & 72.98 & 3.3 & $1 / 21 / 1999$ & 745 & $\mathrm{C} 000020$ & $1 / 22 / 1999$ & $15: 55$ & 106 & 900 & 917 & 1267 & 350 & 39 & 752.7 & 84.4 & 7.1 & 0.8 & 0.1 \\
\hline 30 & 24.31 & 120.14 & 3.7 & $1 / 21 / 1999$ & 754 & $\mathrm{C} 000014$ & $1 / 22 / 1999$ & $13: 57$ & 84 & 900 & 917 & 1304 & 387 & 39 & 832.2 & 85.7 & 9.9 & 1 & 0.1 \\
\hline 31 & 25.8 & 57.25 & 0.2 & $1 / 21 / 1999$ & 1307 & C000010 & $1 / 22 / 1999$ & $12: 31$ & 98 & 900 & 917 & 1139 & 222 & 37 & 477.4 & 80.1 & 4.9 & 0.8 & 0.1 \\
\hline 32 & 26.92 & 52.01 & 2.3 & $1 / 21 / 1999$ & 759 & $\mathrm{C} 000006$ & $1 / 24 / 1999$ & 12:04 & 95 & 900 & 947 & 1107 & 160 & 37 & 343.5 & 79.1 & 3.6 & 0.8 & 0.1 \\
\hline 33 & 27.3 & -5.64 & 2.2 & $1 / 21 / 1999$ & 910 & $\mathrm{C} 000022$ & $1 / 22 / 1999$ & $16: 51$ & 91 & 900 & 917 & 1332 & 415 & 40 & 892.4 & 86.7 & 9.9 & 1 & 0.1 \\
\hline 34 & 28.79 & 104.42 & 0.2 & $1 / 21 / 1999$ & 1253 & $\mathrm{C} 000017$ & $1 / 22 / 1999$ & $15: 00$ & 97 & 900 & 917 & 1075 & 158 & 36 & 339.8 & 77.9 & 3.5 & 0.8 & 0.1 \\
\hline 35 & 29.91 & 4.85 & 0.4 & $1 / 21 / 1999$ & 1302 & $\mathrm{C} 000016$ & $1 / 22 / 1999$ & $14: 37$ & 95 & 900 & 917 & 1089 & 172 & 36 & 369.9 & 78.4 & 3.9 & 0.8 & 0.1 \\
\hline 36 & 3.03 & 16.64 & 2.7 & $1 / 21 / 1999$ & 917 & $\mathrm{C} 000004$ & $1 / 24 / 1999$ & $11: 27$ & 97 & 900 & 947 & 1122 & 175 & 37 & 375.8 & 79.6 & 3.9 & 0.8 & $0: 1$ \\
\hline 37 & 3.4 & 100.49 & 0.5 & $1 / 21 / 1999$ & 1303 & $\mathrm{C} 000043$ & $1 / 23 / 1999$ & $14: 38$ & 92 & 900 & 957 & 1207 & 250 & 38 & 537.1 & 82.4 & 5.8 & 0.9 & 0.1 \\
\hline 38 & 30.28 & 88.7 & 3.1 & $1 / 21 / 1999$ & 820 & $\mathrm{C} 000007$ & $1 / 24 / 1999$ & $12: 24$ & 93 & 900 & 947 & 1059 & 112 & 36 & 240.3 & 77.6 & 2.6 & 0.8 & 0.1 \\
\hline 39 & 31.78 & 32.8 & 2.6 & $1 / 21 / 1999$ & 924 & $\mathrm{C} 000011$ & $1 / 22 / 1999$ & $12: 48$ & 96 & 900 & 917 & 1037 & 120 & 36 & 258.1 & 76.7 & 2.7 & 0.8 & 0.1 \\
\hline 40 & 32.52 & 103.55 & 0.8 & $1 / 21 / 1999$ & 1308 & C000009 & $1 / 22 / 1999$ & $11: 19$ & 90 & 900 & 917 & 1103 & 186 & 37 & 400 & 78.9 & 4.4 & 0.9 & 0.1 \\
\hline 41 & 32.9 & 59.87 & 2.6 & 1/21/1999 & 833 & $\mathrm{C} 000003$ & $1 / 24 / 1999$ & 11:09 & 90 & 900 & 947 & 1278 & 331 & 39 & 711.3 & 84.8 & 7.9 & 0.9 & 0.1 \\
\hline 42 & 33.27 & 17.95 & 3.6 & $1 / 21 / 1999$ & 930 & $\mathrm{C} 000023$ & $1 / 22 / 1999$ & 17:08 & 89 & 900 & 917 & 1089 & 172 & 36 & 369.9 & 78.4 & 4.1 & 0.9 & 0.1 \\
\hline 43 & 34.76 & 80.84 & 1.2 & $1 / 21 / 1999$ & 937 & $\mathrm{C} 000040$ & $1 / 23 / 1999$ & $13: 46$ & 90 & 900 & 957 & 1056 & 99 & 36 & 212.4 & 77.5 & 2.4 & 0.9 & 0.1 \\
\hline
\end{tabular}


Table B.1. (continued)

\begin{tabular}{|c|c|c|c|c|c|c|c|c|c|c|c|c|c|c|c|c|c|c|c|}
\hline $\begin{array}{c}\text { Location } \\
\text { No. }\end{array}$ & $X(m)$ & $\mathrm{Y}(\mathrm{m})$ & $\mathrm{Z}(\mathrm{ft})$ & $\begin{array}{l}\text { Date } \\
\text { collected }\end{array}$ & Time & ANS No. & $\begin{array}{l}\text { Date } \\
\text { counted }\end{array}$ & Time & $\begin{array}{l}\text { Weight } \\
\text { (g) }\end{array}$ & $\begin{array}{l}\text { Live } \\
\text { time (s) }\end{array}$ & $\begin{array}{l}\text { Ambient } \\
\text { back- } \\
\text { ground } \\
\text { counts }\end{array}$ & $\begin{array}{l}\text { Gross } \\
\text { counts }\end{array}$ & $\begin{array}{l}\text { Net } \\
\text { counts }\end{array}$ & Sigma & $\begin{array}{l}\text { Gross } \\
\text { activity } \\
\text { (pCi) }\end{array}$ & Sigma & $\begin{array}{l}\text { Specific } \\
\text { activity } \\
\text { (pCi/g) }\end{array}$ & Sigma & $\begin{array}{c}\mathrm{MDC} \\
(\mathrm{pCi} / \mathrm{g})\end{array}$ \\
\hline 44 & 36.26 & 49.39 & 2.3 & $1 / 21 / 1999$ & 944 & $\mathrm{C} 000023$ & $1 / 24 / 1999$ & $18: 26$ & 94 & 900 & 947 & 1112 & 165 & 37 & 354.3 & 79.3 & 3.8 & 0.8 & 0.1 \\
\hline 45 & 38.87 & 28.43 & 1.4 & $1 / 21 / 1999$ & 1015 & $\mathrm{C} 000013$ & $1 / 22 / 1999$ & $13: 28$ & 96 & 900 & 917 & 1238 & 321 & 38 & 690.3 & 83.4 & 7.2 & 0.9 & 0.1 \\
\hline 46 & 39.24 & 112.28 & 1 & $1 / 21 / 1999$ & 1309 & $\mathrm{C} 000008$ & $1 / 22 / 1999$ & $11: 02$ & 90 & 900 & 917 & 1227 & 310 & 38 & 666.6 & 83.1 & 7.4 & 0.9 & 0.1 \\
\hline 47 & -4.07 & 21 & 1.4 & $1 / 21 / 1999$ & 1311 & $\mathrm{C} 000007$ & $1 / 22 / 1999$ & $10: 42$ & 94 & 900 & 917 & 1276 & 359 & 39 & 772 & 84.8 & 8.2 & 0.9 & 0.1 \\
\hline 48 & 4.89 & 69.04 & 1.1 & $1 / 21 / 1999$ & 1314 & $\mathrm{C} 000033$ & $1 / 23 / 1999$ & $10: 32$ & 103 & 900 & 931 & 1224 & 293 & 38 & 630.1 & 83 & 6.1 & 0.8 & 0.1 \\
\hline 49 & 40.74 & 33.67 & 2.5 & $1 / 21 / 1999$ & 1007 & $\mathrm{C} 000018$ & $1 / 22 / 1999$ & $15: 20$ & 101 & 900 & 917 & 1190 & 273 & 38 & 587.1 & 81.8 & 5.8 & 0.8 & 0.1 \\
\hline 50 & 41.86 & 75.6 & 1.7 & $1 / 21 / 1999$ & 1022 & $\mathrm{C} 000025$ & $1 / 22 / 1999$ & $17: 44$ & 96 & 900 & 917 & 1261 & 344 & 39 & 739.8 & 84.2 & 7.7 & 0.9 & 0.1 \\
\hline 51 & 42.23 & 96.56 & 4 & $1 / 21 / 1999$ & 1030 & $\mathrm{C} 000038$ & $1 / 23 / 1999$ & $13: 08$ & 84 & 900 & 957 & 1084 & 127 & 36 & 272.6 & 78.4 & 3.2 & 0.9 & 0.1 \\
\hline 52 & 43.73 & 56.38 & 2.7 & $1 / 21 / 1999$ & 1000 & C000019 & $1 / 22 / 1999$ & $15: 38$ & 104 & 900 & 917 & 1085 & 168 & 36 & 361.3 & 78.3 & 3.5 & 0.8 & 0.1 \\
\hline 53 & 44.85 & 122.76 & 2.8 & $1 / 21 / 1999$ & 1036 & $\mathrm{C} 000051$ & $1 / 23 / 1999$ & $17: 10$ & 92 & 900 & 957 & 1359 & 402 & 40 & 864 & 87.6 & 9.4 & 1 & 0.1 \\
\hline 54 & 45.22 & 65.11 & 2.8 & $1 / 21 / 1999$ & 952 & C000049 & $1 / 23 / 1999$ & $16: 34$ & 90 & 900 & 957 & 1318 & 361 & 39 & 775.8 & 86.2 & 8.6 & 1 & 0.1 \\
\hline 55 & 46.71 & 128 & 1 & $1 / 21 / 1999$ & 1315 & $\mathrm{C} 000041$ & $1 / 23 / 1999$ & $14: 05$ & 96 & 900 & 957 & 1236 & 279 & 38 & 599.4 & 83.4 & 6.3 & 0.9 & 0.1 \\
\hline 56 & 47.83 & 2.22 & 3.4 & $1 / 21 / 1999$ & 1316 & $\mathrm{C} 000042$ & $1 / 23 / 1999$ & $14: 22$ & 93 & 900 & 957 & 1275 & 318 & 39 & 683.3 & 84.7 & 7.3 & 0.9 & 0.1 \\
\hline 57 & 48.21 & 137.83 & 1.6 & $1 / 21 / 1999$ & 1318 & $\mathrm{C} 000034$ & $1 / 23 / 1999$ & $11: 09$ & 89 & 900 & 931 & 6167 & 5236 & 80 & 11259.9 & 277.2 & 125.9 & 3.1 & 0.1 \\
\hline 58 & 49.7 & 74.94 & 3 & $1 / 21 / 1999$ & 1330 & $\mathrm{C} 000050$ & $1 / 23 / 1999$ & $16: 54$ & 88 & 900 & 957 & 1875 & 918 & 46 & 1973.6 & 106 & 22.4 & 1.2 & 0.1 \\
\hline 59 & -5.56 & 61.18 & 1.4 & $1 / 21 / 1999$ & 1342 & $\mathrm{C} 000004$ & $1 / 22 / 1999$ & $9: 40$ & 96 & 900 & 917 & 1136 & 219 & 37 & 471 & 80 & 4.9 & 0.8 & 0.1 \\
\hline 60 & -5.94 & -6.95 & 2 & $1 / 22 / 1999$ & 806 & $\mathrm{C} 000008$ & $1 / 24 / 1999$ & $12: 41$ & 90 & 900 & 947 & 1590 & 643 & 43 & 1382.2 & 95.7 & 15.4 & 1.1 & 0.1 \\
\hline 61 & 50.82 & 69.7 & 3.5 & $1 / 22 / 1999$ & 755 & C000009 & $1 / 24 / 1999$ & $12: 58$ & 93 & 900 & 947 & 1155 & 208 & 37 & 446.8 & 80.7 & 4.8 & 0.9 & 0.1 \\
\hline 62 & 51.19 & 12.05 & 3.9 & $1 / 22 / 1999$ & 801 & $\mathrm{C} 000010$ & $1 / 24 / 1999$ & $13: 19$ & 92 & 900 & 947 & 1149 & 202 & 37 & 433.9 & 80.5 & 4.7 & 0.9 & 0.1 \\
\hline 63 & 52.69 & 122.11 & 1.1 & $1 / 22 / 1999$ & 811 & $\mathrm{C} 000011$ & $1 / 24 / 1999$ & $13: 35$ & 89 & 900 & 947 & 1300 & 353 & 39 & 758.6 & 85.6 & 8.5 & I & 0.1 \\
\hline 64 & 53.81 & 22.53 & 2 & $1 / 22 / 1999$ & 816 & $\mathrm{C} 000012$ & $1 / 24 / 1999$ & $14: 23$ & 98 & 900 & 947 & 1074 & 127 & 36 & 272.6 & 78 & 2.8 & 0.8 & 0.1 \\
\hline 65 & 54.18 & 43.5 & 2.9 & $1 / 22 / 1999$ & 820 & $\mathrm{C} 000029$ & $1 / 23 / 1999$ & $9: 20$ & 84 & 900 & 931 & 1239 & 308 & 38 & 662.3 & 83.5 & 7.9 & 1 & 0.1 \\
\hline 66 & 55.67 & 3.32 & 3.2 & $1 / 22 / 1999$ & 822 & $\mathrm{C} 000013$ & $1 / 24 / 1999$ & $14: 42$ & 83 & 900 & 947 & 1180 & 233 & 38 & 500.5 & 81.5 & 6 & 1 & 0.1 \\
\hline 67 & 56.42 & 50.48 & 2.5 & $1 / 22 / 1999$ & 830 & $\mathrm{C} 000014$ & $1 / 24 / 1999$ & $14: 59$ & 98 & 900 & 947 & 1318 & 371 & 39 & 797.3 & 86.2 & 8.2 & 0.9 & 0.1 \\
\hline 68 & 56.79 & 6.81 & 1.8 & $1 / 22 / 1999$ & 835 & $\mathrm{C} 000016$ & $1 / 24 / 1999$ & $15: 35$ & 97 & 900 & 947 & 1019 & 72 & 35 & 154.3 & 76.3 & 1.6 & 0.8 & 0.1 \\
\hline 69 & 57.17 & 106.39 & 2.6 & $1 / 22 / 1999$ & 840 & C000017 & $1 / 24 / 1999$ & $15: 59$ & 97 & 900 & 947 & 1228 & 281 & 38 & 603.7 & 83.1 & 6.2 & 0.9 & 0.1 \\
\hline 70 & 58.66 & 27.77 & 2.5 & $1 / 22 / 1999$ & 845 & $\mathrm{C} 000018$ & $1 / 24 / 1999$ & $16: 21$ & 97 & 900 & 947 & 1112 & 165 & 37 & 354.3 & 79.3 & 3.6 & 0.8 & 0.1 \\
\hline 71 & 59.78 & 90.66 & 3.2 & $1 / 21 / 1999$ & 1333 & $\mathrm{C} 000002$ & $1 / 24 / 1999$ & $10: 48$ & 91 & 900 & 947 & 1190 & 243 & 38 & 522 & 81.9 & 5.8 & 0.9 & 0.1 \\
\hline 72 & 6.01 & 110.97 & 1 & $1 / 22 / 1999$ & 849 & $\mathrm{C} 000019$ & $1 / 24 / 1999$ & $16: 39$ & 87 & 900 & 947 & 1153 & 206 & 37 & 442.5 & 80.6 & 5.1 & 0.9 & 0.1 \\
\hline 73 & 6.39 & -9.57 & 2.6 & $1 / 22 / 1999$ & 854 & $\mathrm{C} 000020$ & $1 / 24 / 1999$ & $16: 57$ & 90 & 900 & 947 & 1060 & 113 & 36 & 242.5 & 77.6 & 2.7 & 0.9 & 0.1 \\
\hline 74 & 60.15 & -3.67 & 2.4 & $1 / 22 / 1999$ & 902 & $\mathrm{C} 000021$ & $1 / 24 / 1999$ & $17: 14$ & 92 & 900 & 947 & 1306 & 359 & 39 & 771.5 & 85.8 & 8.4 & 0.9 & 0.1 \\
\hline 75 & 62.77 & 116.87 & 2.2 & $1 / 22 / 1999$ & 910 & $\mathrm{C} 000022$ & $1 / 24 / 1999$ & $18: 08$ & 92 & 900 & 947 & 1161 & 214 & 37 & 459.7 & 80.9 & 5 & 0.9 & 0.1 \\
\hline 76 & 63.14 & 59.22 & 2.8 & $1 / 22 / 1999$ & 915 & $\mathrm{C} 000024$ & 1/24/1999 & $18: 43$ & 90 & 900 & 947 & 1159 & 212 & 37 & 455.4 & 80.8 & 5.1 & 0.9 & 0.1 \\
\hline 77 & 65.75 & 46.12 & 0.9 & $1 / 22 / 1999$ & 920 & $\mathrm{C} 000025$ & $1 / 24 / 1999$ & $19: 02$ & 93 & 900 & 947 & 1075 & 128 & 36 & 274.7 & 78.1 & 2.9 & 0.8 & 0.1 \\
\hline 78 & 66.13 & 114.25 & 4 & $1 / 22 / 1999$ & 927 & $\mathrm{C} 000026$ & $1 / 24 / 1999$ & 19:18 & 97 & 900 & 947 & 1185 & 238 & 38 & 511.3 & 81.7 & 5.3 & 0.8 & 0.1 \\
\hline 79 & 67.62 & 74.07 & 0.7 & $1 / 22 / 1999$ & 933 & $\mathrm{C} 000027$ & $1 / 24 / 1999$ & $19: 39$ & 84 & 900 & 947 & 1175 & 228 & 38 & 489.8 & 81.4 & 5.8 & $\begin{array}{r}.0 \\
1\end{array}$ & 0.1 \\
\hline 80 & 68.74 & 140.45 & 3 & $1 / 22 / 1999$ & 939 & $\mathrm{C} 000028$ & $1 / 24 / 1999$ & $19: 55$ & 85 & 900 & 947 & 1185 & 238 & 38 & 511.3 & 81.7 & 6 & 1 & 0.1 \\
\hline 81 & 69.12 & 82.8 & 0.8 & $1 / 22 / 1999$ & 942 & $\mathrm{C} 000029$ & $1 / 24 / 1999$ & 20:11 & 89 & 900 & 947 & 1152 & 205 & 37 & 440.3 & 80.6 & 4.9 & 0.9 & 0.1 \\
\hline 82 & 70.61 & 98.52 & 2.4 & $1 / 22 / 1999$ & 944 & $\mathrm{C} 000030$ & $1 / 24 / 1999$ & $20: 28$ & 92 & .900 & 947 & 1234 & 287 & 38 & 616.6 & 83.3 & 6.7 & 0.9 & 0.1 \\
\hline 83 & 71.73 & 19.91 & 3.4 & $1 / 22 / 1999$ & 949 & $\mathrm{C} 000031$ & $1 / 24 / 1999$ & $20: 44$ & 88 & 900 & 947 & 1215 & 268 & 38 & 575.8 & 82.7 & 6.6 & 0.9 & 0.1 \\
\hline 84 & 72.1 & 67.08 & 1.7 & $1 / 22 / 1999$ & 953 & $\mathrm{C} 000032$ & $1 / 24 / 1999$ & $21: 01$ & 90 & 900 & 947 & 1241 & 294 & 38 & 631.7 & 83.6 & 7 & 0.9 & 0.1 \\
\hline $\begin{array}{l}04 \\
85\end{array}$ & 73.6 & $\begin{array}{r}4.00 \\
4.19\end{array}$ & 1.2 & $1 / 22 / 1999$ & 957 & $\mathrm{C} 000033$ & $1 / 24 / 1999$ & $21: 19$ & 93 & 900 & 947 & 1124 & 177 & 37 & 380.1 & 79.7 & 4.1 & 0.9 & 0.1 \\
\hline 86 & 7472 & -105 & 12 & $1 / 22 / 1999$ & 1040 & $\mathrm{C} 000038$ & $1 / 25 / 1999$ & $7: 56$ & 98 & 900 & 993 & 2462 & 1469 & 59 & 3159.1 & 140.3 & 32.3 & 1.4 & 0.1 \\
\hline
\end{tabular}


Table B.1. (continued)

\begin{tabular}{|c|c|c|c|c|c|c|c|c|c|c|c|c|c|c|c|c|c|c|c|}
\hline $\begin{array}{l}\text { Location } \\
\text { No. }\end{array}$ & $X(\mathrm{~m})$ & $\mathrm{Y}(\mathrm{m})$ & $Z(\mathrm{ft})$ & $\begin{array}{c}\text { Date } \\
\text { collected }\end{array}$ & Time & ANS No. & $\begin{array}{l}\text { Date } \\
\text { counted }\end{array}$ & Time & $\begin{array}{l}\text { Weight } \\
\text { (g) }\end{array}$ & $\begin{array}{l}\text { Live } \\
\text { time (s) }\end{array}$ & $\begin{array}{l}\text { Ambient } \\
\text { back- } \\
\text { ground } \\
\text { counts }\end{array}$ & $\begin{array}{l}\text { Gross } \\
\text { counts }\end{array}$ & $\begin{array}{l}\text { Net } \\
\text { counts }\end{array}$ & Sigma & $\begin{array}{l}\text { Gross } \\
\text { activity } \\
\text { (pCi) }\end{array}$ & Sigma & $\begin{array}{l}\text { Specific } \\
\text { activity } \\
\text { (pCi/g) }\end{array}$ & Sigma & $\begin{array}{c}\mathrm{MDC} \\
(\mathrm{pCi} / \mathrm{g})\end{array}$ \\
\hline 87 & 75.09 & 129.97 & 3.6 & $1 / 22 / 1999$ & 1049 & C000039 & $1 / 25 / 1999$ & $8: 13$ & 91 & 900 & 993 & 1162 & 169 & 46 & 363.4 & 100.1 & 4 & 1.1 & 0.1 \\
\hline 88 & 76.58 & 51.36 & 0.3 & $1 / 22 / 1999$ & 1056 & $\mathrm{C} 000040$ & $1 / 25 / 1999$ & $8: 30$ & 92 & 900 & 993 & 1100 & 107 & 46 & 230.1 & 98.5 & 2.5 & 1.1 & 0.1 \\
\hline 89 & 77.7 & 93.28 & 1.4 & $1 / 22 / 1999$ & 1100 & C000041 & $1 / 25 / 1999$ & 8:50 & 89 & 900 & 993 & 1449 & 456 & 49 & 980.6 & 107.9 & 11 & 1.2 & 0.1 \\
\hline 90 & 78.08 & 35.63 & 0.2 & $1 / 22 / 1999$ & 1110 & $\mathrm{C} 000042$ & $1 / 25 / 1999$ & $9: 06$ & 90 & 900 & 993 & 992 & -1 & 45 & -2.2 & 95.8 & 0 & 1.1 & 0.1 \\
\hline 91 & -8.55 & 76.91 & 0.3 & $1 / 22 / 1999$ & 1220 & $\mathrm{C} 000043$ & $1 / 25 / 1999$ & $9: 33$ & 95 & 900 & 993 & 1322 & 329 & 48 & 707.5 & 104.4 & 7.5 & 1.1 & 0.1 \\
\hline 92 & 8.63 & -2.58 & 1.6 & $1 / 22 / 1999$ & 1225 & $\mathrm{C} 000044$ & $1 / 25 / 1999$ & $9: 56$ & 95 & 900 & 993 & 1175 & 182 & 47 & 391.4 & 100.4 & 4.1 & 1.1 & 0.1 \\
\hline 93 & 80.32 & 15.11 & 3.2 & $1 / 22 / 1999$ & 1231 & $\mathrm{C} 000045$ & $1 / 25 / 1999$ & $10: 16$ & 89 & 900 & 993 & 1140 & 147 & 46 & 316.1 & 99.5 & 3.5 & 1.1 & 0.1 \\
\hline 94 & 81.06 & 71.01 & 2.5 & $1 / 22 / 1999$ & 1237 & $\mathrm{C} 000046$ & $1 / 25 / 1999$ & $10: 37$ & 85 & 900 & 993 & 1241 & 248 & 47 & 533.3 & 102.2 & 6.3 & 1.2 & 0.1 \\
\hline 95 & 85.54 & 39.57 & 1.5 & $1 / 22 / 1999$ & 1242 & $\mathrm{C} 000047$ & $1 / 25 / 1999$ & $11: 20$ & 86 & 900 & 993 & 1143 & 150 & 46 & 322.6 & 99.6 & 3.8 & 1.2 & 0.1 \\
\hline 96 & 87.04 & 23.84 & 3.5 & $1 / 22 / 1999$ & 1247 & C000005 & $1 / 24 / 1999$ & $11: 44$ & 92 & 900 & 947 & 1199 & 252 & 38 & 541.4 & 82.2 & 5.9 & 0.9 & 0.1 \\
\hline 97 & 9 & 95.25 & 3.8 & $1 / 22 / 1999$ & 1255 & $\mathrm{C} 000048$ & 1/25/1999 & $12: 18$ & 96 & 900 & 993 & 1127 & 134 & 46 & 288.2 & 99.2 & 3 & 1 & 0.1 \\
\hline 98 & 9.37 & 53.32 & 0.3 & 1/22/1999 & 1259 & C000049 & $1 / 25 / 1999$ & $12: 38$ & 93 & 900 & 993 & 1041 & 48 & 45 & 103.2 & 97 & 1.1 & 1 & 0.1 \\
\hline 99 & 90.03 & 8.12 & 1.5 & $1 / 22 / 1999$ & 1304 & $\mathrm{C} 000050$ & $1 / 25 / 1999$ & $12: 54$ & 93 & 900 & 993 & 1037 & 44 & 45 & 94.6 & 96.9 & 1 & 1 & 0.1 \\
\hline 100 & 92.64 & 34.32 & 1.1 & $1 / 22 / 1999$ & 1308 & $\mathrm{C} 000051$ & $1 / 25 / 1999$ & $13: 14$ & 94 & 900 & 993 & 1135 & 142 & 46 & 305.4 & 99.4 & 3.3 & 1.1 & 0.1 \\
\hline 101 & 95.63 & 55.29 & 3.1 & $1 / 22 / 1999$ & 1312 & $\mathrm{C} 000052$ & $1 / 25 / 1999$ & $13: 31$ & 90 & 900 & 993 & 1273 & 280 & 48 & 602.1 & 103 & 6.7 & 1.1 & 0.1 \\
\hline 102 & 96 & 31.7 & 0.3 & $1 / 22 / 1999$ & 1319 & $\mathrm{C} 000053$ & $1 / 25 / 1999$ & $13: 48$ & 90 & 900 & 993 & 1623 & 630 & 51 & 1354.8 & 113.1 & 15.1 & 1.3 & 0.1 \\
\hline 103 & 98.99 & 47.43 & 1.3 & $1 / 22 / 1999$ & 1324 & $\mathrm{C} 000054$ & $1 / 25 / 1999$ & 14:06 & 94 & 900 & 993 & 1130 & 137 & 46 & 294.6 & 99.2 & 3.1 & 1.1 & 0.1 \\
\hline
\end{tabular}

${ }^{a}$ Collected by EKR/RMS

ANS = American Nuclear Systems

$\mathrm{MDC}=$ minimum detectable concentration. 
Table B.2. Background counts

\begin{tabular}{|c|c|c|c|c|c|c|}
\hline ANS No. & Date & Time & $\begin{array}{l}\text { Weight } \\
\text { (g) }\end{array}$ & $\begin{array}{l}\text { Live time } \\
\text { (s) }\end{array}$ & $\begin{array}{c}\text { Ambient } \\
\text { background counts }\end{array}$ & Gross counts \\
\hline B000004 & $1 / 20 / 1999$ & $18: 45$ & 0 & 3600.00 & 0 & 3979 \\
\hline B000006 & $1 / 20 / 1999$ & $21: 41$ & 0 & 46870.62 & 0 & 50125 \\
\hline B000007 & $1 / 21 / 1999$ & $8: 28$ & 0 & 3600.00 & 0 & 0 \\
\hline B000016 & $1 / 21 / 1999$ & $17: 49$ & 0 & 49030.64 & 0 & 51503 \\
\hline B000017 & $1 / 22 / 1999$ & $.7: 26$ & 0 & 3600.00 & 0 & 3668 \\
\hline B000026 & $1 / 22 / 1999$ & $18: 05$ & 0 & 49827.87 & 0 & 51787 \\
\hline B000027 & $1 / 23 / 1999$ & $7: 56$ & 0 & 3600.00 & 0 & 3724 \\
\hline B000037 & $1 / 23 / 1999$ & $7: 56$ & 0 & 3600.00 & 0 & 3829 \\
\hline $\mathrm{B} 000001$ & $1 / 24 / 1999$ & $8: 54$ & 0 & 3600.00 & 0 & 3789 \\
\hline
\end{tabular}

b

Table B.3. Duplicates

\begin{tabular}{|c|c|c|c|c|c|c|c|c|c|c|c|c|c|c|c|c|c|c|c|}
\hline Location & $\underset{(\mathrm{m})}{\mathrm{X}}$ & $\underset{(\mathrm{m})}{\mathrm{Y}}$ & $\underset{(\mathrm{ft})}{\mathrm{Z}}$ & $\begin{array}{c}\text { Date } \\
\text { collected }\end{array}$ & Time & ANS No. & $\begin{array}{c}\text { Date } \\
\text { counted }\end{array}$ & Time & $\begin{array}{l}\text { Weight } \\
\text { (g) }\end{array}$ & $\begin{array}{l}\text { Live } \\
\text { time } \\
(s)\end{array}$ & $\begin{array}{l}\text { Ambient } \\
\text { back- } \\
\text { ground } \\
\text { counts }\end{array}$ & $\begin{array}{l}\text { Gross } \\
\text { counts }\end{array}$ & $\begin{array}{l}\text { Net } \\
\text { counts }\end{array}$ & Sigma & $\begin{array}{l}\text { Gross } \\
\text { activity } \\
\text { (pCi) }\end{array}$ & Sigma & $\begin{array}{l}\text { Specific } \\
\text { activity } \\
\text { (pCi/g) }\end{array}$ & Sigma & $\underset{(\mathrm{pCi} / \mathrm{g})}{\mathrm{MDC}}$ \\
\hline 6 & 10.87 & 116.21 & 3.4 & $1 / 21 / 1999$ & $16: 48$ & D000013 & $1 / 21 / 1999$ & $16: 48$ & 83 & 900 & 927 & 1033 & 107 & 36 & 229 & 76.6 & 2.8 & 0.9 & 0.1 \\
\hline 28 & 22.82 & 10.09 & 0.1 & $1 / 22 / 1999$ & $10: 18$ & D000006 & $1 / 22 / 1999$ & $10: 18$ & 88 & 900 & 917 & 1375 & 458 & 40 & 984.9 & 88.2 & 11.2 & 1 & 0.1 \\
\hline 29 & 23.94 & 72.98 & 3.3 & $1 / 22 / 1999$ & $16: 16$ & D000021 & $1 / 22 / 1999$ & $16: 16$ & 106 & 900 & 917 & 1223 & 306 & 38 & 658 & 82.9 & 6.2 & 0.8 & 0.1 \\
\hline 57 & 48.21 & 137.83 & 1.6 & $1 / 23 / 1999$ & $11: 28$ & D000035 & $1 / 23 / 1999$ & $11: 28$ & 89 & 900 & 931 & 6112 & 5181 & 80 & 11141.6 & 274.9 & 124.6 & 3.1 & 0.1 \\
\hline 10 & 109.44 & 38.69 & 1.3 & $1 / 23 / 1999$ & 16:18 & D000048 & $1 / 23 / 1999$ & $16: 18$ & 95 & 900 & 957 & 1632 & 675 & 43 & 1451 & 97.2 & 15.3 & 1 & 0.1 \\
\hline
\end{tabular}


Appendix $\mathrm{C}$

QC RESULTS FROM ORNL ANALYTICAL LABORATORY

\section{?}


Table C.1. QC results from ORNL analytical laboratory

\begin{tabular}{rccccc}
\hline Location & ANS No. & Date & $\begin{array}{c}\text { ANS specific } \\
\text { activity } \\
\text { (pCi/g) }\end{array}$ & $\begin{array}{c}\text { QC specific } \\
\text { activity } \\
\text { (pCi/g) }\end{array}$ & $\begin{array}{c}\text { Relative } \\
\text { percent } \\
\text { difference }\end{array}$ \\
\hline 57 & C000034 & $1 / 23 / 1999$ & 125.9 & 98.72 & 24.2008726 \\
22 & C000008 & $1 / 21 / 1999$ & 37.8 & 26.531 & 35.0344313 \\
86 & C000038 & $1 / 25 / 1999$ & 32.3 & 38.871 & -18.4654 \\
58 & C000050 & $1 / 23 / 1999$ & 22.4 & 18.51 & 19.01736 \\
28 & C000005 & $1 / 22 / 1999$ & 16 & 1.6042 & 163.5496 \\
10 & C000047 & $1 / 23 / 1999$ & 15.5 & 11.723 & 27.7485949 \\
60 & C000008 & $1 / 24 / 1999$ & 15.4 & 8.638 & 56.2609202 \\
102 & C000053 & $1 / 25 / 1999$ & 15.1 & 19.127 & -23.53113 \\
23 & C000007 & $1 / 21 / 1999$ & 13.7 & 28.999 & -71.659758 \\
25 & C000003 & $1 / 21 / 1999$ & 12.2 & 6.787 & 57.01796 \\
89 & C000041 & $1 / 25 / 1999$ & 11 & 5.1828 & 71.8936154 \\
14 & C000010 & $1 / 21 / 1999$ & 10.5 & 5.4913 & 62.642812 \\
20 & C000009 & $1 / 21 / 1999$ & 9.9 & 2.7765 & 112.389066 \\
30 & C000014 & $1 / 22 / 1999$ & 9.9 & 4.6275 & 72.5864739 \\
33 & C000022 & $1 / 22 / 1999$ & 9.9 & 8.638 & 13.6152767 \\
53 & C000051 & $1 / 23 / 1999$ & 9.4 & 4.936 & 62.2767857 \\
54 & C000049 & $1 / 23 / 1999$ & 8.6 & 8.638 & -0.4408864 \\
63 & C000011 & $1 / 24 / 1999$ & 8.5 & 21.595 & -87.024423 \\
74 & C000021 & $1 / 24 / 1999$ & 8.4 & 8.021 & 4.61604044 \\
47 & C000007 & $1 / 22 / 1999$ & 8.2 & 2.0361 & 120.434541 \\
67 & C000014 & $1 / 24 / 1999$ & 8.2 & 3.8254 & 72.7559998 \\
12 & C000015 & $1 / 21 / 1999$ & 7.9 & 5.6764 & 32.7568428 \\
26 & C000015 & $1 / 22 / 1999$ & 7.9 & 6.787 & 15.1562606 \\
41 & C000003 & $1 / 24 / 1999$ & 7.9 & 6.0466 & 26.5785209 \\
65 & C000029 & $1 / 23 / 1999$ & 7.9 & 5.3679 & 38.1688135 \\
50 & C000025 & $1 / 22 / 1999$ & 7.7 & 3.4552 & 76.1044177 \\
27 & C000045 & $1 / 23 / 1999$ & 7.6 & 4.6892 & 47.3716759 \\
91 & C000043 & $1 / 25 / 1999$ & 7.5 & 3.2084 & 80.1538979 \\
46 & C000008 & $1 / 22 / 1999$ & 7.4 & 3.4552 & 72.6803744 \\
56 & C000042 & $1 / 23 / 1999$ & 7.3 & 1.9744 & 114.845165 \\
45 & C000013 & $1 / 22 / 1999$ & 7.2 & 2.8999 & 85.1513381 \\
3 & C000014 & $1 / 21 / 1999$ & 7.1 & 3.7637 & 61.4210628 \\
\hline
\end{tabular}

${ }^{a}$ Value from on-site radioanalytical laboratory.

${ }^{b}$ Value from QC third party analyzed in Oak Ridge, Tennessee. 
C-4 


\section{INTERNAL DISTRIBUTION}

\author{
1-6. M. J. Wilson-Nichols \\ 7. C. A. Little \\ 8. R. M. Schlosser \\ 9. P. V. Egidi
}

10. E. K. Roemer

11. Central Research Library

12-13. Laboratory Records (OSTI)

14. Laboratory Records (RC)

\section{EXTERNAL DISTRIBUTION}

15-19. Major D. Rynders, Defense Threat Reduction Agency, Attn: NSIAE, 1680 Texas Street, S.E., Kirtland AFB, NM 87117-5669

20. Office of Assistant Manager, Energy Research and Development, Oak Ridge Operations Office, P.O. Box 2001, Oak Ridge, TN 37831-8600

21. H. Stumpf, Defense Threat Reduction Agency, Attn: LEE, 45045 Aviation Drive, Dulles, VA 20166-7517

22. J. Eddy, Headquarters Defense Threat Reduction Agency, Attn: LE, 45045 Aviation Drive, Dulles, VA 20166-7517

23. J. R. Davidson, Battelle Pacific Northwest Laboratory, P.O. Box 999, MS K5-12, Richland, Washington 00352 
